\title{
ton
}

Instituto de Pesquisas Energéticas e Nucleares

Autarquia Associada à Universidade de São Paulo

\section{EFEITO DA ADIÇÃO DE ÓXIDO DE COBALTO NA SINTERIZAÇÃO E NA CONDUTIVIDADE ELÉTRICA DA ZIRCÔNIA ESTABILIZADA COM ÍTRIA}

\section{GRAZIELA CRISTIANE TELLES DA SILVA}

\author{
Dissertação apresentada como parte \\ dos requisitos para obtenção do Grau \\ de Mestre em Ciências na Área de \\ Tecnologia Nuclear - Materiais. \\ Orientadora: \\ Dra . Eliana Navarro S. Muccillo
}

São Paulo

2008 
"Aprender é a única coisa de que a mente nunca se cansa, nunca tem medo e nunca se arrepende."

Leonardo da Vinci 


\section{AGRADECIMENTOS}

Queria agradecer...

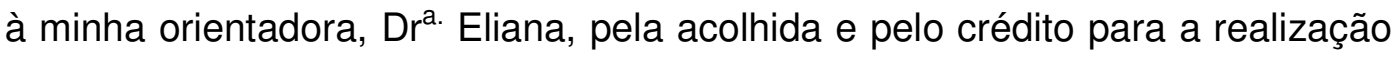
deste trabalho,

ao Dr. Reginaldo Muccillo pelas sugestões e discussões,

ao CNPq pela bolsa de mestrado concedida,

ao Ipen pela oportunidade de realizar este trabalho,

ao Centro de Ciências e Tecnologia de Materiais, pelas análises de MEV, Termogravimetria e DRX realizadas,

ao PROCEL pelas medidas de dilatometria,

ao laboratório de espectroscopia molecular do Instituto de Química da USP/SP pelas medidas de espectroscopia Raman,

ao laboratório de Ceramografia, em especial a $\mathrm{Dr}^{\mathrm{a}}$ Ana Helena, pelas sugestões no preparo das amostras para MEV,

aos doutores, mestres, técnicos e colegas do CCTM pelas valiosas discussões, não podendo me esquecer dos amigos Shirley, Eliel, Ferrari, Olavo, Emilene e Rafael,

às meninas, Tamiye, Deiby, Renata, Érica, Carla e Christiane, pelas valiosas sugestões e discussões feitas no café e no bolo da química,

em especial as amigas Heveline e Priscila por esses 2 anos de convivência e pelos momentos de descontração e

a todos que direta ou indiretamente contribuíram para a realização deste trabalho.

A toda a minha família, Gercilea, Manoel, Giovana (André) e Alexandra, sem eles eu nada seria. E ao Dimitri pela paciência e apoio durante a execução deste trabalho. 


\title{
Efeito da Adição de Óxido de Cobalto na Sinterização e na Condutividade Elétrica da Zircônia Estabilizada com Ítria
}

\author{
Graziela Cristiane Telles da Silva
}

\section{RESUMO}

A zircônia estabilizada com ítria é um material com diversas aplicações tecnológicas. Uma de suas aplicações é como eletrólito sólido em células a combustível de óxido sólido. Os pós de zircônia estabilizada com ítria disponíveis comercialmente densificam a temperaturas superiores a $1400 \stackrel{\circ}{ }$. Redução na temperatura de sinterização da zircônia seria muito útil, pois permitiria a realização da sinterização simultânea ("co-firing") do eletrólito sólido e do anodo, implicando em redução de custo do processo na fabricação de células a combustível. Neste trabalho, os efeitos produzidos do Co na densificação da 8YSZ, principalmente em baixos teores do aditivo, foi estudado, como também a condutividade elétrica da zircônia-estabilizada com ítria, visando determinar o efeito da adição de Co. Foram preparados compactos com carbonato de cobalto e 8YSZ comercial em composições 8YSZ + x\% mol Co com x =0;0,025;0,05;0,1;0,25;0,5; $1 ; 2 ; 3 ; 4 ; 5 ; 7,5$ e 10, por prensagem seguida de sinterização ao ar em diversas temperaturas e tempo de patamar. Os compactos sinterizados foram caracterizados por diversas técnicas. A espectroscopia Raman e a difração de raios $X$ permitiram identificar o $\mathrm{Co}_{3} \mathrm{O}_{4}$ como fase predominante após a sinterização, quando o aditivo excede o limite de solubilidade. A densidade sinterizada aumentou com a adição de pequenos teores de Co, mas não foi suficiente para reduzir a temperatura de sinterização abaixo de $1400 \stackrel{\circ}{\circ}$. O tamanho médio de grãos aumentou com a temperatura de sinterização. A condutividade elétrica diminui com a adição de Co para teores $\geq 1 \% \mathrm{~mol}$, mas apresenta pequeno aumento para teores de $0,025 \%$ mol.

Palavras-chave: zircônia, sinterização, condutividade elétrica, aditivos cerâmicos. 


\title{
Effect of Cobalt Oxide on Sintering and Electrical Conductivity of Yttria Stabilized Zirconia
}

\section{Graziela Cristiane Telles da Silva}

\begin{abstract}
Yttria stabilized zirconia has a wide range of applications including electrochemical devices, oxygen sensors and permeable membranes. Yttria stabilized zirconia is the preferred solid electrolyte in current solid oxide fuel cells. Commercially available yttria stabilized zirconia powders are usually sintered at temperatures higher than $140{ }^{\circ} \mathrm{C}$. Reduction of the sintering temperature is desirable to allow for co-firing the solid electrolyte and the anode materials, thereby reducing the fabrication cost. In this work, the effects produced by small amounts of Co addition on sintering and on electrical conductivity of $8 Y S Z$ were investigated. Green compacts were prepared by uniaxial pressing mixtures of $8 Y S Z+x$ mol\% Co with $x=0 ; 0.025 ; 0.05 ; 0.1$; $0.25 ; 0.5 ; 1 ; 2 ; 3 ; 4 ; 5 ; 7.5$ and 10 followed by sintering at different dwell temperatures and soaking times. Several techniques were used to characterize the sintered compacts. Results of Raman spectroscopy along with those of Xray diffraction allowed for the identification of the cobalt oxide formed $\left(\mathrm{Co}_{3} \mathrm{O}_{4}\right)$ when the solubility limit is exceeded. The sintered density increased with small Co additions. However, the sintering temperature is still around $1400{ }^{\circ} \mathrm{C}$. The average grain size increased with Co addition and with increase of the sintering temperature. The electrical conductivity remains almost unchanged with Co additions up to $0.5 \mathrm{~mol} \%$ and decreases for higher additive contents. However, a small increase of the electrical conductivity occurs at $0.025 \mathrm{~mol} \%$ Co.
\end{abstract}

Keywords: zirconia, sintering, electrical conductivity, additives. 


\section{ÍNDICE}

1- INTRODUÇÃO

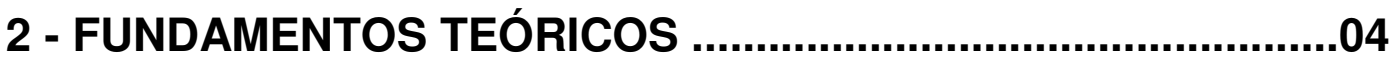

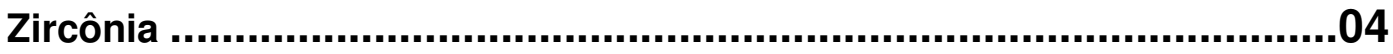

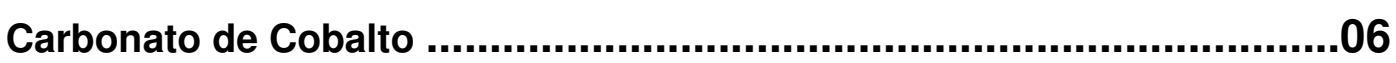

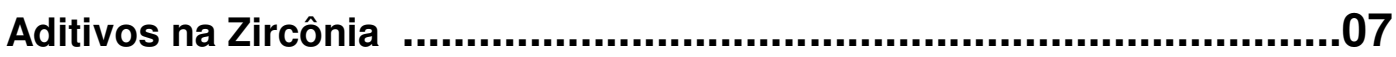

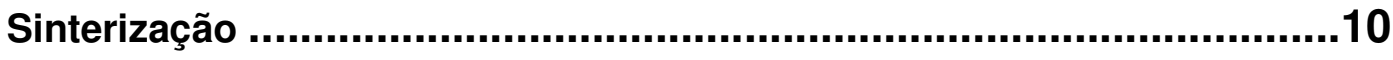

Sinterização por reação em estado sólido ..............................................11

Sinterização por fase líquida ............................................................14

Técnicas de Caracterização .........................................................15

Análise Térmica (Termogravimetria - TG) ..............................................15

Densidade ..........................................................................16

Microscopia Eletrônica de Varredura (MEV) ……..................................18

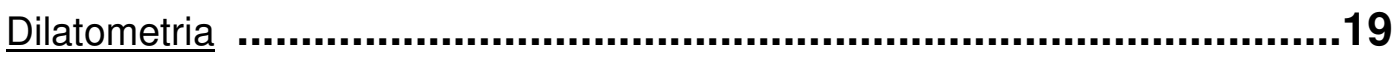

Difração de Raios X ..................................................................20

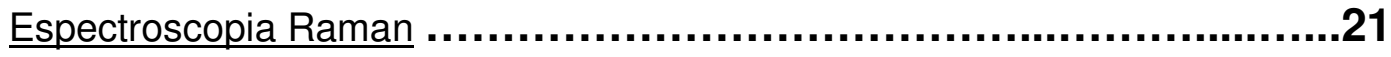

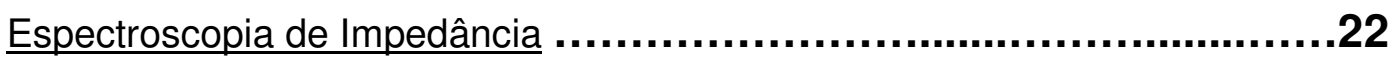

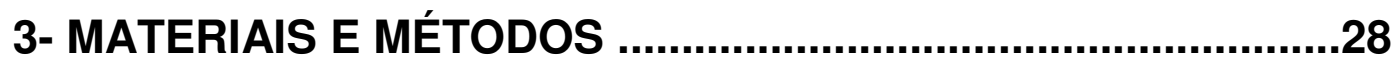

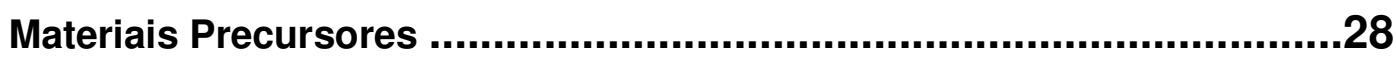

Elaboração dos corpos de Prova ..................................................29

Técnicas de Caracterização ............................................................31

Análise térmica (Termogravimetria - TG) ............................................31

Densidade ................................................................................32

Microscopia Eletrônica de Varredura ....................................................32 
Dilatometria

Difração de Raios X .......................................................................34

Espectroscopia Raman .....................................................................34

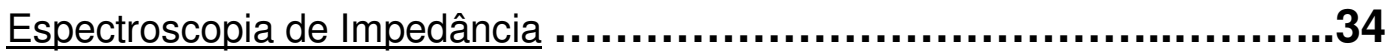

4 - RESULTADOS E DISCUSSÃO ...........................................36

5 - CONCLUSÕES .............................................................60

6 - REFERÊNCIAS BIBLIOGRÁFICAS ...................................61 


\section{LISTA DE FIGURAS}

FIGURA 1 - Representação esquemática das estruturas cristalinas da zircônia..........................................................................................04

FIGURA 2 - Representação de mudanças microestruturais durante a sinterização por reação em estado sólido. (a) Partículas soltas de pó; (b) Estágio inicial;(c) Estágio intermediário e (d) Estágio final. ..........................12

FIGURA 3 - Esquema que representa as trajetórias de transporte de massa no estágio inicial da sinterização utilizando o modelo de duas partículas............13

FIGURA 4 - Esquema de retração versus tempo de sinterização, na sinterização por fase líquida 15

FIGURA 5 - Representação de uma célula eletroquímica composta pelo eletrólito sólido e pela camada de metal em cada uma das faces .23

FIGURA 6 - Representação do vetor impedância no plano complexo .24

FIGURA 7 - Representação do diagrama de impedância. $R$ = resistência de cada um dos componentes ( $\mathrm{g}=$ grão; $\mathrm{cg}$ = contorno de grão e el = eletrodo), $\omega$ $=$ freqüência angular, e a seta corresponde à direção do aumento da freqüência

FIGURA 8 - Fotos do misturador mecânico (Túrbula, modelo T2C), utilizado no processo de homogeneização

FIGURA 9 - Diagrama de blocos da metodologia utilizada para a mistura dos pós precursores e elaboração dos corpos de prova 
FIGURA 10 - Foto da câmara de medidas elétricas para até três amostras.

FIGURA 11 - Desenho esquemático do porta-amostra utilizado para as medidas de espectroscopia de impedância

FIGURA 12 - Curva termogravimétrica (TG) do carbonato de cobalto .37

FIGURA 13 - Micrografia obtida em microscópio eletrônico de varredura do pó precursor 8YSZ

FIGURA 14 - Micrografia obtida em microscópio eletrônico de varredura da mistura $8 \mathrm{YSZ}+1,0 \% \mathrm{~mol}$ Co (superior), $8 \mathrm{YSZ}+5,0 \%$ mol Co (centro), $8 \mathrm{YSZ}+$ $10,0 \%$ mol Co (inferior)

38

FIGURA 15 - Espectro de raios X por energia dispersiva da região mais escura, (A), do aglomerado de $8 \mathrm{YSZ}+10,0 \% \mathrm{~mol}$ Co .39

FIGURA 16 - Espectro de raios X por energia dispersiva da região mais clara, (B), do aglomerado de $8 \mathrm{YSZ}+10,0 \% \mathrm{~mol}$ Co .39

FIGURA 17 - Curvas de retração linear em função da temperatura das amostras $8 Y S Z+x \%$ mol Co, onde $x=0 ; 0,1 ; 0,25 ; 0,5$ e 1,0 .41

FIGURA 18 - Micrografias obtidas em microscópio eletrônico de varredura de superfícies de fratura das amostras 8YSZ (superior), $8 Y S Z+5 \%$ (centro) e $8 Y S Z+10 \%$ mol Co (inferior), sinterizadas a $1300 \stackrel{\circ}{\circ} / 0,5 \mathrm{~h}$

FIGURA 19 - Difratogramas de raios $X$ das amostras sinterizadas a $1200{ }^{\circ} \mathrm{C} /$ 0,5 h. (a) $8 Y S Z+5,0 \%$ mol Co, (b) $8 Y S Z+7,5 \%$ mol Co e (c) $8 Y S Z+10,0 \%$ em mol de Co; ${ }^{*}: \mathrm{CO}_{3} \mathrm{O}_{4}$ 
FIGURA 20 - Espectros Raman das amostras 8YSZ sinterizada a $1300{ }^{\circ} \mathrm{C} / 0,5$ h e $8 Y S Z+10,0 \%$ mol Co sinterizada a $1200 \stackrel{\circ}{C} / 0,5 \mathrm{~h}$

FIGURA 21 - Micrografias obtidas em microscópio eletrônico de varredura de superfícies polidas e atacadas termicamente das amostras $8 Y S Z+1,0 \% \mathrm{~mol}$ de Co (superior), $8 \mathrm{YSZ}+5,0 \% \mathrm{~mol}$ de Co (centro), e $8 \mathrm{YSZ}+10,0 \% \mathrm{~mol}$ de Co (inferior), sinterizadas a $1300 \stackrel{\circ}{\circ} \mathrm{C} / 0,5 \mathrm{~h}$

FIGURA 22 - Densidades das amostras sinterizadas a $1300 \stackrel{\circ}{\circ} / 0,5 \mathrm{~h}$ .47

FIGURA 23 - Micrografias obtidas em microscópio eletrônico de varredura de superfícies polidas e atacadas termicamente das amostras 8YSZ (superior), $8 Y S Z+0,5 \% \mathrm{~mol}$ Co (centro), $8 Y S Z+1,0 \% \mathrm{~mol} \mathrm{Co}$ (inferior), sinterizadas a $1400 \stackrel{\circ}{C} / 0,5 \mathrm{~h}$

FIGURA 24 - Densidade hidrostática das amostras sinterizadas em diversas temperaturas e tempos de patamar em função do teor de Co .50

FIGURA 25 - Diagramas de impedância das amostras 8YSZ e 8YSZ + $\mathrm{x} \% \mathrm{~mol}$ Co, onde $x=0,05$ e 0,5 . Amostras sinterizadas a $1300{ }^{\circ} \mathrm{C} / 0,5 \mathrm{~h}$. .51

FIGURA 26 - Gráficos de Arrhenius da condutividade elétrica total das amostras $8 Y S Z$ e $8 Y S Z+x \%$ mol Co, onde $x=0,05 ; 0,1 ; 0,5 ; 1,0 ; 5,0 ; 7,5$ e 10,0 . Amostras sinterizadas a $1300 \stackrel{\circ}{\circ} / 0,5 \mathrm{~h}$ .52

FIGURA 27 - Diagramas de impedância das amostras 8YSZ e 8YSZ + x\% mol Co, onde $x=0,05$ e 0,5 . Amostras sinterizadas a $1400 \stackrel{\circ}{C} / 0,1 \mathrm{~h}$. .53

FIGURA 28 - Gráficos de Arrhenius da condutividade elétrica dos grãos das amostras 8YSZ e 8YSZ+ $x \%$ mol Co, onde $x=0,025 ; 0,05 ; 0,25$ e 0,5 . Amostras sinterizadas a $1400 \stackrel{\circ}{\circ} / 0,1 \mathrm{~h}$ 
FIGURA 29 - Gráficos de Arrhenius da condutividade elétrica dos contornos de grão das amostras $8 Y S Z$ e $8 Y S Z+x \%$ mol Co, onde $x=0,025 ; 0,05 ; 0,25$ e 0,5 . Amostras sinterizadas a $1400 \stackrel{\circ}{\circ} / 0,1 \mathrm{~h}$

FIGURA 30 - Diagramas de impedância de amostras 8YSZ e 8YSZ + $\mathrm{x} \% \mathrm{~mol}$ Co com $\mathrm{x}=0,05$ e 0,5 sinterizadas a $1400^{\circ} \mathrm{C} / 0,5 \mathrm{~h}$ .55

FIGURA 31 - Gráficos de Arrhenius da condutividade elétrica dos grãos das amostras $8 Y S Z$ e $8 Y S Z+x \%$ mol Co, onde $\mathrm{x}=0,025 ; 0,05 ; 0,25 ; 0,5$ e 1,0 . Amostras sinterizadas a $1400{ }^{\circ} \mathrm{C} / 0,5 \mathrm{~h}$ .56

FIGURA 32 - Gráficos de Arrhenius da condutividade elétrica dos contornos de grão das amostras $8 Y S Z$ e $8 Y S Z+x \%$ mol Co, onde $x=0,025 ; 0,05 ; 0,25 ; 0,5$ e 1,0 . Amostras sinterizadas a $1400 \stackrel{\circ}{\circ} \mathrm{C} / 0,5 \mathrm{~h}$ .56 


\section{LISTA DE TABELAS}

TABELA 1 - Propriedades e características do óxido de cobalto

TABELA 2 - Mecanismos de transporte de matéria no estágio inicial de sinterização por reações em estado sólido

TABELA 3 - Teores de impurezas e características físicas da zircônia estabilizada com ítria, fornecidos pelo fabricante .28

TABELA 4 - Valores de densidades geométrica e hidrostática das amostras $8 Y S Z+0,5 \%$ mol Co, sinterizadas a $1300 \stackrel{\circ}{\circ} / 1 \mathrm{~h}$

TABELA 5 - Valores de energia de raios X característicos dos diversos elementos

TABELA 6 - Valores de temperatura de início da retração e da temperatura na qual a retração é máxima, obtidos das curvas de retração linear das amostras $8 Y S Z+x \%$ mol Co, com $x=0 ; 0,1 ; 0,25 ; 0,5$ e 1,0

TABELA 7 - Valores de tamanho médio de grãos (G), obtidos pelo método de Mendelson, para amostras sinterizadas a $1300^{\circ} \mathrm{C} / 0,5 \mathrm{~h}$ .48

TABELA 8 - Valores de tamanho médio de grãos $(G)$, obtidos pelo método de Mendelson, para amostras sinterizadas a $1400{ }^{\circ} \mathrm{C} / 0,5 \mathrm{~h}$ .50

TABELA 9 - Valores de energia de ativação do processo de condução nos grãos, contornos de grão e total, para amostras sinterizadas a $1300 \stackrel{\circ}{\circ}$ / $0,5 \mathrm{~h}$. 
TABELA 10 - Valores de energia de ativação do processo de condução nos grãos, contornos de grão e total, para amostras sinterizadas a $1400 \stackrel{\circ}{\mathrm{C}} / 0,1 \mathrm{~h}$

TABELA 11 - Valores de energia de ativação do processo de condução nos grãos, contornos de grão e total, para amostras sinterizadas a $1400 \stackrel{\circ}{\mathrm{C}} / 0,5 \mathrm{~h}$ 


\section{1- INTRODUÇÃO}

Neste item será feita uma breve introdução sobre o material de interesse neste trabalho, suas principais características e aplicações, além da motivação para este estudo.

Desde a metade do século $\mathrm{XX}$, desenvolveu-se um enorme interesse nas cerâmicas de alta tecnologia. Este interesse surgiu devido as propriedades elétricas, mecânicas, térmicas e químicas que poderiam permitir o uso destes materiais em eletrônica e para fins estruturais. Esses novos materiais, com propriedades bem definidas, denominados cerâmicas avançadas, requerem matérias-primas cujas composições são cuidadosamente controladas [1].

Nessa classe de materiais, são considerados todos aqueles obtidos com matérias-primas puras, normalmente sintéticas e processadas em condições muito controladas, a fim de fornecer propriedades superiores.

As cerâmicas avançadas são usadas em muitas indústrias que exigem alta tecnologia, como aeroespacial, eletrônica, biomédica, automotiva, etc.

Um dos exemplos de matéria-prima utilizada em cerâmicas avançadas é a zircônia [2].

A zircônia tanto pura quanto contendo aditivos é um material que tem atraído a atenção de muitos pesquisadores. Isto se deve a combinação de suas propriedades mecânicas, químicas e elétricas. A importância das cerâmicas avançadas contendo zircônia torna-se cada vez maior, com aplicações nos mais variados campos da tecnologia como, componentes de dispositivos eletrônicos, peças estruturais e de revestimento, ferramentas de corte, sensores de oxigênio, bombas de oxigênio, membranas permeáveis ao oxigênio, em biocerâmicas e como eletrólito sólido em células a combustível de óxido sólido [3, 4].

A zircônia totalmente estabilizada com ítria na fase cúbica apresenta valores de condutividade iônica elevados acima de $400{ }^{\circ} \mathrm{C}$. Entretanto, os pós de zircônia estabilizada com ítria disponíveis comercialmente densificam a 
temperaturas superiores a $1400{ }^{\circ} \mathrm{C}$. Redução na temperatura de sinterização da zircônia seria muito útil, pois permitiria a realização da sinterização simultânea ("co-firing") do eletrólito sólido e do anodo, implicando em redução de custo do processo na fabricação de células a combustível.

Uma das abordagens utilizadas para a diminuição da temperatura de sinterização em materiais cerâmicos consiste em utilizar métodos nãoconvencionais de sinterização como, por exemplo, a sinterização assistida por pressão, que acelera a cinética de sinterização. Outra possibilidade é o uso de aditivos que promovam a densificação, em temperaturas mais baixas que as usuais evitando o crescimento de grãos.

Neste contexto, é importante que o aditivo esteja em pequenos teores de tal forma a não interferir com as propriedades macroscópicas e microscópicas da cerâmica sinterizada. Além disso, é também importante que o aditivo esteja homogeneamente disperso na matriz.

São exemplos desses aditivos, $\mathrm{B}_{2} \mathrm{O}_{3}[5], \mathrm{Fe}_{2} \mathrm{O}_{3}, \mathrm{Bi}_{2} \mathrm{O}_{3}[6]$ e $\mathrm{La}_{2} \mathrm{O}_{3}$ [7] que adicionados à zircônia estabilizada com ítria, promovem redução da temperatura de sinterização.

Relativamente poucos trabalhos foram realizados utilizando o Co como aditivo de sinterização, e assim o seu efeito na densificação e na condutividade elétrica da zircônia estabilizada com ítria não está totalmente entendido.

Desta forma, os principais objetivos deste trabalho foram estudar os efeitos produzidos por adições de Co na densificação da zircônia estabilizada com $8 \%$ mol de ítria (8YSZ), principalmente para pequenos teores do aditivo; analisar a microestrutura do pó e das cerâmicas sinterizadas; e identificar a(s) fase(s) do aditivo quando presente em teores acima do limite de solubilidade na zircônia.

Além de verificar o efeito do Co nestas propriedades, este trabalho também teve como objetivo estudar possíveis interferências do aditivo na condutividade elétrica da zircônia estabilizada, uma vez que, em células a combustível de óxido sólido, o eletrólito sólido está em contato direto com os eletrodos, sendo que pelo menos um deles pode conter em sua composição o metal de transição em estudo. 
No capítulo 2, serão descritas características da zircônia e do óxido de cobalto, envolvendo uma revisão dos trabalhos publicados, bem como das técnicas de caracterização utilizadas.

No capítulo 3, os materiais e métodos serão apresentados e em seguida no capítulo 4, são mostrados e discutidos os resultados obtidos.

No capítulo 5, serão apresentadas as conclusões do trabalho. 


\section{2 - FUNDAMENTOS TEÓRICOS}

Neste capítulo serão abordados aspectos relevantes dos materiais em estudo, algumas propriedades e técnicas de caracterização utilizadas.

\section{Zircônia}

A zircônia pode apresentar diversas estruturas cristalinas sendo que as mais conhecidas são: monoclínica, tetragonal e cúbica [8], de acordo com o diagrama de fases [9]. Quando a zircônia pura é submetida a ciclos de aquecimento e resfriamento, há a transformação de fases como mostra a fiqura $1[10,11]$.

- átomo de zircônio

átomo de oxigênio

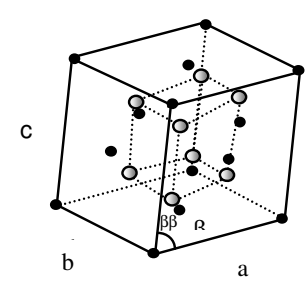

monoclínica

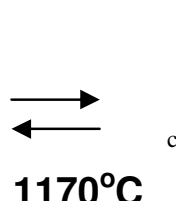

$1170^{\circ} \mathrm{C}$

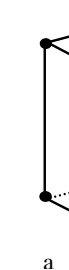

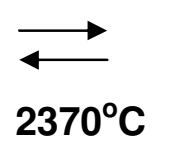

a

tetragonal

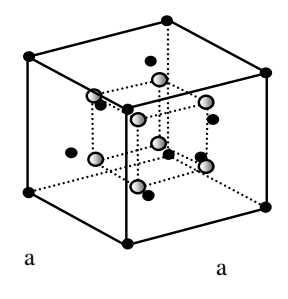

cúbica

FIGURA 1 - Representação esquemática das estruturas cristalinas da zircônia.

A fase monoclínica é estável até aproximadamente $1170{ }^{\circ} \mathrm{C}$. Em temperaturas mais altas transforma-se em tetragonal, na qual é estável até $2370{ }^{\circ} \mathrm{C}$, quando se transforma em cúbica de faces centradas.

A zircônia por apresentar estas transformações de fases cristalinas, não é indicada para aplicações tecnológicas em sua forma pura, pois durante a transformação da fase tetragonal para monoclínica, ocorre expansão volumétrica, com variação de 3 a 5\% do seu volume [9]. Isto resulta em uma 
ruptura estrutural da cerâmica. Para evitar essa transformação de fase é usual o emprego de aditivos com a finalidade de estabilizar a estrutura cristalina de alta temperatura à ambiente [4]. Os aditivos mais utilizados na zircônia comercial são o $\mathrm{MgO}, \mathrm{CaO}$ e $\mathrm{Y}_{2} \mathrm{O}_{3}$.

A estabilização da zircônia pode ser total ou parcial. A zircônia parcialmente estabilizada, uma mistura de fases cúbica com monoclínica ou tetragonal, é obtida quando a quantidade de aditivos presentes for inferior à necessária para completar a estabilização, ou quando a zircônia cúbica é submetida a tratamentos térmicos sob condições apropriadas de tempo e temperatura. Essas cerâmicas apresentam altas resistência mecânica e tenacidade à fratura [9].

A zircônia em alguns casos pode ser estabilizada na fase tetragonal pela incorporação de certos óxidos em proporções específicas. Em outros casos, a estrutura tetragonal pode ser obtida para baixos teores do óxido estabilizante $\left(\mathrm{Y}_{2} \mathrm{O}_{3}\right.$ e $\left.\mathrm{CaO}\right)$, escolhendo-se o tamanho inicial das partículas e as condições de sinterização. A zircônia estabilizada na fase tetragonal tem aplicação comercial como ferramenta de corte, material abrasivo, e outras finalidades estruturais [9].

A zircônia estabilizada totalmente na fase cúbica é um condutor puramente iônico em amplas faixas de temperatura e pressão parcial de oxigênio [12]. Em virtude disso, a zircônia totalmente estabilizada é empregada em diversas áreas como eletrólito sólido e suas aplicações mais importantes são em sensores de oxigênio e em células a combustível de óxido sólido (SOFC).

Outros aditivos cerâmicos também podem ser usados na zircônia durante seu processamento. Diversos aditivos podem, por exemplo, ser utilizados como auxiliares de sinterização, para evitar o crescimento de grãos ou para promover a densificação em temperaturas mais baixas que as usuais [5- 7]. 


\section{Carbonato de Cobalto}

Uma característica importante do carbonato de cobalto é a variação de valência dos seus óxidos resultantes, quando submetido a aquecimento e resfriamento [13].

El-Shobaky [13], observou que a curva da análise térmica diferencial (DTA) do hydroxycarbonato de cobalto apresenta 4 picos endotérmicos, o $1^{\circ}$ corresponde perda de água adsorvida a $100{ }^{\circ} \mathrm{C}$, o $2^{\circ}$ e $3^{\circ}$, com máximos em 250 e $350{ }^{\circ} \mathrm{C}$, respectivamente, correspondem à perda de massa de água estrutural e decomposição do $\mathrm{CoCO}_{3}$ para $\mathrm{Co}_{3} \mathrm{O}_{4}$ [14]. Esta decomposição corresponde à reação:

$5 \mathrm{CoCO}_{3} . \mathrm{Co}(\mathrm{OH})_{2}+\mathrm{O}_{2}(\mathrm{~g}) \stackrel{225-375^{\circ} \mathrm{C}}{\longrightarrow} 2 \mathrm{Co}_{3} \mathrm{O}_{4}+5 \mathrm{CO}_{2}(\mathrm{~g})+\mathrm{H}_{2} \mathrm{O}(\mathrm{g})$

O óxido de cobalto produzido permanece estável até $850{ }^{\circ} \mathrm{C}$, quando sofre nova decomposição [15]. O último pico endotérmico a $940{ }^{\circ} \mathrm{C}$, que vem acompanhado de perda de massa, corresponde a completa conversão de $\mathrm{Co}_{3} \mathrm{O}_{4} \mathrm{em} \mathrm{CoO}$, conforme a reação:

$$
\mathrm{Co}_{3} \mathrm{O}_{4} \stackrel{850-980{ }^{\circ} \mathrm{C}}{\longrightarrow} 3 \mathrm{CoO}+1 / 2 \mathrm{O}_{2}(\mathrm{~g})
$$

Durante o resfriamento a partir de $1000{ }^{\circ} \mathrm{C}$ em atmosfera de oxigênio, o $\mathrm{CoO}$ tende a reoxidar formando o $\mathrm{Co}_{3} \mathrm{O}_{4}[15]$.

$\mathrm{Na}$ tabela 1, são mostradas algumas características do óxido de cobalto de acordo com sua valência. 
TABELA 1 - Propriedades e características do óxido de cobalto.

\begin{tabular}{|c|c|c|c|c|c|}
\hline Óxido & $\begin{array}{l}\text { Estrutura } \\
\text { cristalina } \\
\text { (JCPDS) }\end{array}$ & $\begin{array}{c}\text { Parâmetros } \\
\text { de rede (Å) } \\
\text { (JCPDS) }\end{array}$ & $\begin{array}{c}\text { Massa } \\
\text { Molecular } \\
(\mathrm{g} / \mathrm{mol}) \\
{[16]}\end{array}$ & $\begin{array}{c}\text { Densidade } \\
\left(\mathrm{g} / \mathrm{cm}^{3}\right) \\
{[16]}\end{array}$ & $\begin{array}{c}\text { Temperatura } \\
\text { de fusão }\left({ }^{0} \mathrm{C}\right) \\
{[16]}\end{array}$ \\
\hline $\mathrm{CoO}$ & $\begin{array}{c}\text { Cúbica } \\
(42-1300)\end{array}$ & $\begin{array}{c}a=4,54 \\
(42-1300)\end{array}$ & 79,93 & 6,47 & $1795 \pm 20$ \\
\hline $\mathrm{CO}_{2} \mathrm{O}_{3}$ & $\begin{array}{c}\text { Hexagonal } \\
(02-0770)\end{array}$ & $\begin{array}{c}a=4,64 \\
c=5,75 \\
(02-0770)\end{array}$ & 165,86 & 5,18 & $\begin{array}{c}\text { Decomposição } \\
\text { em } 895\end{array}$ \\
\hline $\mathrm{CO}_{3} \mathrm{O}_{4}$ & $\begin{array}{c}\text { Cúbica } \\
(42-1467)\end{array}$ & $\begin{array}{c}a=8,08 \\
(42-1467)\end{array}$ & 240,80 & 6,07 & $\begin{array}{c}\text { Temperatura } \\
\text { de transição } \\
\text { para CoO : } \\
\text { 900-950 }\end{array}$ \\
\hline
\end{tabular}

\section{Aditivos na Zircônia}

O desenvolvimento histórico e as características gerais envolvendo o uso de aditivos em condutores iônicos (condutores de $\mathrm{O}^{2-}, \mathrm{F}^{-}, \mathrm{Ag}^{+}, \mathrm{Cu}^{+}$, etc.) foi bem documentado em quatro artigos revisão [17-20]. Por isso, neste item serão mencionados alguns trabalhos nos quais a zircônia é a matriz, tal que representem as características gerais da influência dos aditivos cerâmicos na microestrutura e na condutividade elétrica da zircônia.

Além do uso de aditivos na zircônia como estabilizadores de fases, outras finalidades são: modificação de propriedades e auxiliares de sinterização. Um exemplo típico de aditivo que modifica as propriedades da cerâmica sinterizada é o $\mathrm{TiO}_{2}$. $\mathrm{Na}$ zircônia nominalmente pura, adições de $\mathrm{TiO}_{2}$ resultam em cerâmicas que apresentam condutividade protônica, podendo ser utilizadas como sensor [21]. Na zircônia estabilizada com ítria, adições de $\mathrm{TiO}_{2}$ promovem a condução eletrônica, tornando o material promissor para uso 
como membrana de separação de oxigênio ou como anodo em célula a combustível de óxido sólido, ou ainda em catálise [22, 23].

Diversos materiais cerâmicos podem ser utilizados como auxiliares de sinterização, para evitar o crescimento exagerado de grãos ou para promover a densificação a temperaturas inferiores às usuais, por meio da formação de fase líquida. Um exemplo típico deste último é a adição de $\mathrm{B}_{2} \mathrm{O}_{3}$ na zircônia estabilizada com ítria [5]. Outro exemplo bastante conhecido é o da adição de $\mathrm{Al}_{2} \mathrm{O}_{3}$ na zircônia. Apesar dos trabalhos encontrados na literatura serem discordantes quanto a alguns aspectos, o que é geralmente aceito é o efeito "scavenger" da alumina na zircônia. Foi demonstrado experimentalmente que a zircônia estabilizada com cálcia contendo $2 \%$ em mol de $\mathrm{Al}_{2} \mathrm{O}_{3}$ apresenta uma fase segregada nos contornos de grão devido à baixa solubilidade da alumina na zircônia. Nesta situação, impurezas de $\mathrm{SiO}_{2}$ que são provenientes dos materiais de partida, e que normalmente ficam também dispersas nos contornos de grão, acabam sendo confinadas nas junções triplas (junções entre três grãos). Como resultado, a condutividade da região dos contornos de grão aumenta, sendo este efeito de confinamento atribuído à alumina [24].

A introdução de $\mathrm{Fe}_{2} \mathrm{O}_{3}$ na zircônia estabilizada com ítria em teores de 0,9\% em mol reduz a temperatura de sinterização, para a obtenção de densidade relativa igual a $95 \%$, por cerca de $150 \stackrel{\circ}{C}$. Enquanto que o aumento no teor do aditivo não resulta em redução adicional significativa na temperatura de sinterização. A condutividade do grão e dos contornos de grão, por outro lado, diminuem linearmente com o aumento no teor do aditivo [6].

A adição de $\mathrm{Bi}_{2} \mathrm{O}_{3}$ na zircônia estabilizada com ítria em teores de 0,74 e 2,20\% em mol promoveu redução na temperatura de sinterização de 150 e 325 ${ }^{\circ} \mathrm{C}$, respectivamente. Análise da microestrutura das cerâmicas sinterizadas revelou a presença de uma fase secundária rica em $\mathrm{ZrO}_{2}$ nos contornos de grão, enquanto que no interior dos grãos foi observado um enriquecimento em ítrio. Isto resultou num forte decréscimo na condutividade dessas amostras [6].

$\mathrm{O}$ efeito da adição de $\mathrm{La}_{2} \mathrm{O}_{3}$, em teores de 0,5 até $5 \%$ em mol, na zircônia estabilizada com ítria foi estudado por meio de análise da microestrutura da cerâmica sinterizada e por espectroscopia de impedância. Para teores de lantânia até 0,5\% em mol obteve-se pequeno aumento na sinterabilidade, e diminuição da densidade sinterizada para teores mais 
elevados. Esse resultado foi explicado pela perda de $\mathrm{La}_{2} \mathrm{O}_{3}$ por evaporação durante a sinterização e conseqüente aumento na porosidade. Resultados de difração de raios $\mathrm{X}$ evidenciaram a formação da fase pirocloro e de $\mathrm{La}_{2} \mathrm{O}_{3}$ livre. A condutividade dos grãos apresentou decréscimo com o aumento no teor de lantânia. Por outro lado, a condutividade dos contornos de grão apresentou o efeito oposto, ou seja, aumento da condutividade com o aumento do teor de lantânia. Entretanto, essas relações do teor de $\mathrm{La}_{2} \mathrm{O}_{3}$ e a condutividade não foram lineares. Como conseqüência, a condutividade total do eletrólito sólido apresentou pequeno aumento para teores de lantânia até $1 \% \mathrm{em}$ mol e diminuiu para teores superiores [7].

Adição de 0,05 ou $0,2 \%$ em massa de $\mathrm{CuO}$ à zircônia tetragonal policristalina (TZP contendo 2,5\% em mol de $\mathrm{Y}_{2} \mathrm{O}_{3}$ ) mostrou que, para esses teores, a condutividade dos grãos é pouco alterada (os valores de energia de ativação para condução são similares, mas há pequena diminuição na condutividade). Isto demonstra que 0 aditivo não produz defeitos (vacâncias de oxigênio) adicionais na matriz. Em contraste, a condutividade dos contornos de grão diminuiu substancialmente com o aumento no teor do aditivo [25].

A incorporação de $\mathrm{Ta}_{2} \mathrm{O}_{5}$ em teores de 0,15 a 2,5\% em mol na zircônia tetragonal policristalina (3Y-TZP) resultou em decréscimo na densidade final do compacto sinterizado e desestabilização da fase tetragonal, além da formação de uma fase secundária do tipo $\mathrm{Ta}_{2} \mathrm{Zr}_{6} \mathrm{O}_{17}$ [26].

$A$ adição simultânea de $\mathrm{Nb}_{2} \mathrm{O}_{5}$ e $\mathrm{Y}_{2} \mathrm{O}_{3}$ à zircônia também foi estudada por diversas técnicas. As cerâmicas foram preparadas por mistura dos óxidos seguida de compactação e sinterização a $1700 \stackrel{\circ}{\circ} \mathrm{C}$. Para teores de $\mathrm{Y}_{2} \mathrm{O}_{3}$ e $\mathrm{Nb}_{2} \mathrm{O}_{5}$ iguais a 15 e $5 \% \mathrm{em}$ mol, respectivamente, foram observadas as fases cúbica tipo fluorita, característica da zircônia estabilizada, e monoclínica. Para todas as composições estudadas verificou-se diminuição da condutividade elétrica em relação à zircônia estabilizada com ítria sem aditivos [27].

Recentemente foi estudado o efeito de adições de manganês (1, 2, 4 e 6 $\%$ em mol de $\mathrm{Mn}_{3} \mathrm{O}_{4}$ ) na zircônia totalmente estabilizada com ítria. Os parâmetros de rede diminuíram com o aumento no teor de manganês, indicando a formação de solução sólida. Resultados de espectroscopia de raios $X$ por energia dispersiva (EDS) mostraram que o manganês ficou distribuído tanto no interior quanto nos contornos de grãos. Assim, parte do aditivo formou 
solução sólida com a matriz de zircônia e parte permaneceu segregada como uma fase secundária nos contornos de grão. Foi determinado o limite de solubilidade do $\mathrm{Mn}_{3} \mathrm{O}_{4}$ na zircônia como $6 \%$ em mol a $1400 \stackrel{\circ}{\circ}$. A adição de $\mathrm{Mn}_{3} \mathrm{O}_{4}$ resultou em decréscimo da condutividade iônica e aumento na energia de ativação do processo de condução. Lembrando que $\circ \mathrm{Mn}_{3} \mathrm{O}_{4}$ formou solução sólida na matriz de zircônia, este resultado foi explicado como decorrente do ordenamento de vacâncias devido a interação destas com o manganês. Por meio de medidas de espectroscopia de impedância foi verificado que para adições de $\mathrm{Mn}_{3} \mathrm{O}_{4}$ inferiores a $4 \%$ em mol, ocorreu diminuição tanto na condutividade dos grãos quanto dos contornos de grão. Para teores superiores, a energia de ativação do processo de condução diminuiu devido ao aumento na condutividade eletrônica [28].

Relativamente poucos trabalhos foram realizados utilizando o Co como aditivo de sinterização. O primeiro estudo foi feito com a adição do óxido de cobalto na zircônia $\left(\mathrm{ZrO}_{2}\right)$ e no silicato de zircônio $\left(\mathrm{ZrSiO}_{4}\right)$. Esse estudo mostrou que a temperatura de densificação máxima foi de $1400^{\circ} \mathrm{C} \mathrm{com} 8 \% \mathrm{em}$ massa do aditivo $\mathrm{CoO}$, no silicato de zircônio $\left(\mathrm{ZrSiO}_{4}\right)$, e para a zircônia $1 \%$ em massa de $\mathrm{CoO}$, temperatura de densificação foi $1600{ }^{\circ} \mathrm{C}$ [29].

Adições em teores relativamente pequenos de $\mathrm{Co}_{2} \mathrm{O}_{3}$ à zircônia- $12 \% \mathrm{~mol}$ ítria (12YSZ) promoveu a densificação da cerâmica com aumento da condutividade para teores de $\mathrm{Co}_{2} \mathrm{O}_{3}$ até $0,5 \%$ em massa na $12 \mathrm{YSZ}$ (equivalente a $0,13 \% \mathrm{~mol}$ de Co na $8 \mathrm{YSZ}$ ), com máximo de condutividade em $0,1 \%$ em massa (equivalente a $0,03 \% \mathrm{~mol}$ de Co) [30]. Estudos anteriores utilizando $5 \%$ em mol de Co revelaram aumento da condutividade da zircônia$8 \%$ mol ítria. Os autores, contudo, propuseram que isto se deveu ao aumento na condução eletrônica [31]. O estudo mais recente, realizado com a zircônia$8 \%$ mol ítria comercial mostrou que a densificação produzida pelo aditivo é significativa, para sinterização a $1450^{\circ} \mathrm{C}$ e altos teores de Co. Contudo, a condutividade diminuiu para todas as composições [32].

\section{Sinterização}


A sinterização é a etapa mais importante ou, pelo menos, uma das mais importantes no processamento de materiais por metalurgia do pó e cerâmica. É nesta etapa que a massa de partículas já conformada ganha resistência mecânica e adquire quase todas as suas propriedades finais [33].

A sinterização é um processo termodinâmico, no qual um sistema de partículas (agregado de pó ou compacto) vem adquirir uma estrutura sólida coerente, através da redução da área superficial específica, resultando na formação de contornos de grão e crescimento de pescoços, de união interpartículas, levando normalmente o sistema à densificação e retração volumétrica.

A formação dos contornos de grão e o crescimento dos pescoços interpartículas ocorrem por mecanismo de transporte de matéria, normalmente processos difusionais atômicos ativados termicamente, preenchendo as regiões de contato interpartículas (poros) até cessar o processo.

As interações entre os fatores geométricos e termodinâmicos são simultâneos e conseqüentes durante todo o processo de sinterização. Porém existe um grau de complexidade entre estes fatores, que não permitiu ainda a elaboração de uma teoria definitiva e consciente do fenômeno, apesar de seu conhecimento tecnológico datar de tempos remotos da civilização [34]. $O$ objetivo do modelo teórico é descrever as relações fundamentais entre os mecanismos de transporte de matéria durante o processo e os parâmetros de sinterização mais importantes tais como, temperatura e tempo de sinterização; forma geométrica, tamanho e distribuição de tamanho das partículas; área da superfície específica; densidade inicial, etc. [35].

No processo de sinterização, dependendo das fases envolvidas, destacam-se basicamente dois tipos de sinterização: por reações no estado sólido e sinterização por fase líquida.

\section{Sinterização por reação em estado sólido}

Neste caso, a matéria é transportada sem que haja qualquer tipo de líquido na estrutura, se houver, seu volume deverá ser insuficiente para ser responsável pela sinterização. Existem diversas formas de transporte de matéria: por difusão atômica (em superfícies, através dos contornos ou em volume) ou por transporte de vapor (materiais com alta pressão de vapor). Em 
todos estes casos, material é transferido para a região de contato entre partículas vizinhas. Outras formas de transporte, até mais eficientes do que estas citadas devem ser consideradas porque envolvem deslocamento de partículas inteiras, como deslizamento e rotação de partículas, e não deslocamento de átomos individuais. Sejam quais forem os mecanismos atuantes, rigidez e densificação são conseguidas pelo aumento da área de contato entre as partículas e o melhor empacotamento de matéria. Outros mecanismos podem ser encontrados em sistemas particulares [35].

Os modelos de sinterização por reação em estado sólido subdividem o processo em três estágios, denominados pela seqüência em [36]:

a) Estágio inicial, caracterizado pela formação de contatos interpartículas, desde a compactação, seguido pela formação e crescimento de pescoços, até o ponto onde eles começam a interferir;

b) Estágio intermediário, caracterizado pela eliminação de poros e conseqüente densificação do compacto, e pelo decréscimo dos diâmetros dos poros interligados;

c) Estágio final, caracterizado pelo crescimento dos grãos e isolamento e possível eliminação gradual da porosidade.

A figura 2, exemplifica a seqüência de estágios.

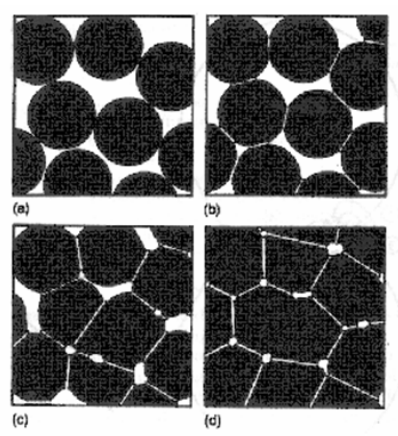

FIGURA 2 - Representação de mudanças microestruturais durante a sinterização por reação em estado sólido. (a) Partículas soltas de pó; (b) Estágio inicial; (c) Estágio intermediário e (d) Estágio final.

No estágio inicial do processo de sinterização por reações em estado sólido são identificados 6 mecanismos de transporte de matéria, figura $3 \mathrm{e}$ tabela 2, que indicam os caminhos do fluxo de massa da força motriz. 
No estágio inicial os mecanismos que conduzem à densificação são aqueles onde a fonte de matéria a ser transferida para a região do pescoço não é a superfície. Ainda assim, a densificação nesse estágio é limitada ( 3 a $\sim 5 \%)$.

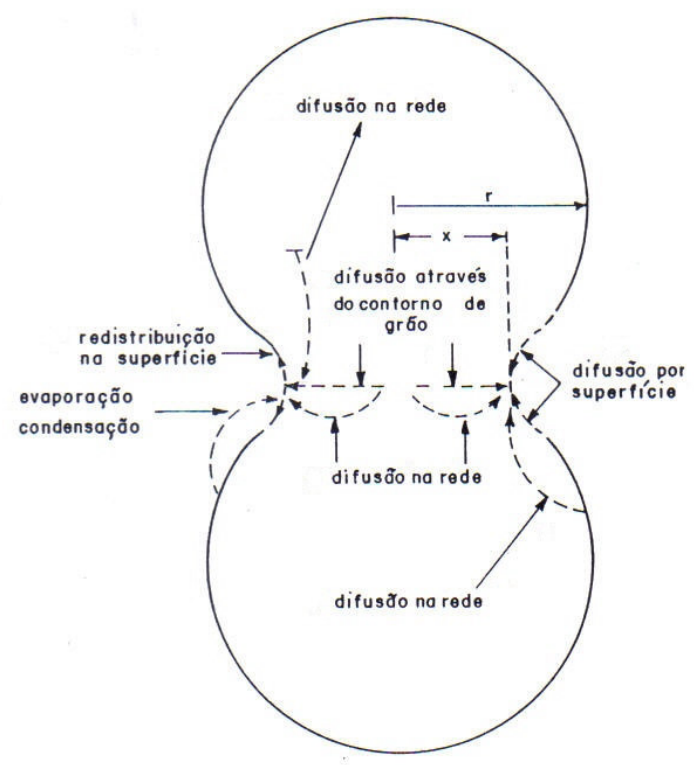

FIGURA 3 - Esquema que representa as trajetórias de transporte de matéria no estágio inicial da sinterização utilizando o modelo de duas partículas.

TABELA 2 - Mecanismos de transporte de matéria no estágio inicial de sinterização por reações em estado sólido.

\begin{tabular}{cccc}
\hline Transporte & Origem & Destino & Densificação \\
\hline $\begin{array}{c}\text { Difusão } \\
\text { superficial } \\
\text { Difusão } \\
\text { volumétrica }\end{array}$ & Superfície & Pescoço & Não \\
$\begin{array}{c}\text { Evaporação- } \\
\text { condensação } \\
\text { Difusão }\end{array}$ & Superfície & Pescoço & Não \\
volumétrica \\
$\begin{array}{c}\text { Difusão } \\
\text { volumétrica } \\
\text { Difusão no }\end{array}$ & Discorno de & Pescoço & Não \\
Contorno de & Pescoço & Sim \\
contorno de grão & grão & Pescoço & Sim \\
\hline
\end{tabular}


O estágio intermediário é aquele no qual a maior parte da porosidade é eliminada. Em geral, os poros são ainda interconectados, mas já se inicia o crescimento dos grãos.

O estágio final é caracterizado pelo crescimento de grãos. Os poros restantes se tornam aprisionados no interior dos grãos e sua eliminação é lenta e difícil.

\section{Sinterização por fase líquida}

A sinterização por fase líquida acontece devido à formação de líquido na estrutura, na temperatura de sinterização. Este líquido pode ser causado pela fusão de um dos componentes do sistema ou pode ser o resultado de uma reação entre, pelo menos, dois dos componentes do sistema. A ocorrência deste líquido tem papel decisivo na determinação dos mecanismos de sinterização e do aspecto final da estrutura sinterizada. A sinterização com fase líquida é um modo bastante atraente de consolidação de materiais dificilmente sinterizáveis por reações no estado sólido e para a obtenção de materiais compósitos [33].

A sinterização por fase líquida ocorre em três estágios [37]:

a) Processo de rearranjo: é o processo subseqüente à formação da fase líquida, responsável pelo rearranjo das partículas sólidas devido à força capilar exercida pelo líquido. Durante este estágio, o compacto comporta-se como um sólido viscoso por causa da ação capilar, e a fração de densificação é dependente da quantidade de líquido formado.

b) Processo de solução/precipitação: é a etapa onde a fase sólida (grãos menores) é dissolvida; difunde no líquido e precipita-se na região de contato, com os grãos maiores que estão sujeitos a menores pressões.

c) Processo final (coalescência): é a etapa controlada pela sinterização por reação em estado sólido, já que o processo de solução/ precipitação foi exaurido. Ocorre a união das partículas sólidas formando um esqueleto rígido, diminuição da densidade de contornos de grão. A densificação é lenta devido à existência do esqueleto sólido, o qual inibe rearranjos adicionais.

A figura 4 exemplifica o comportamento de retração com o tempo de sinterização, assim como os estágios envolvidos neste tipo de sinterização. 


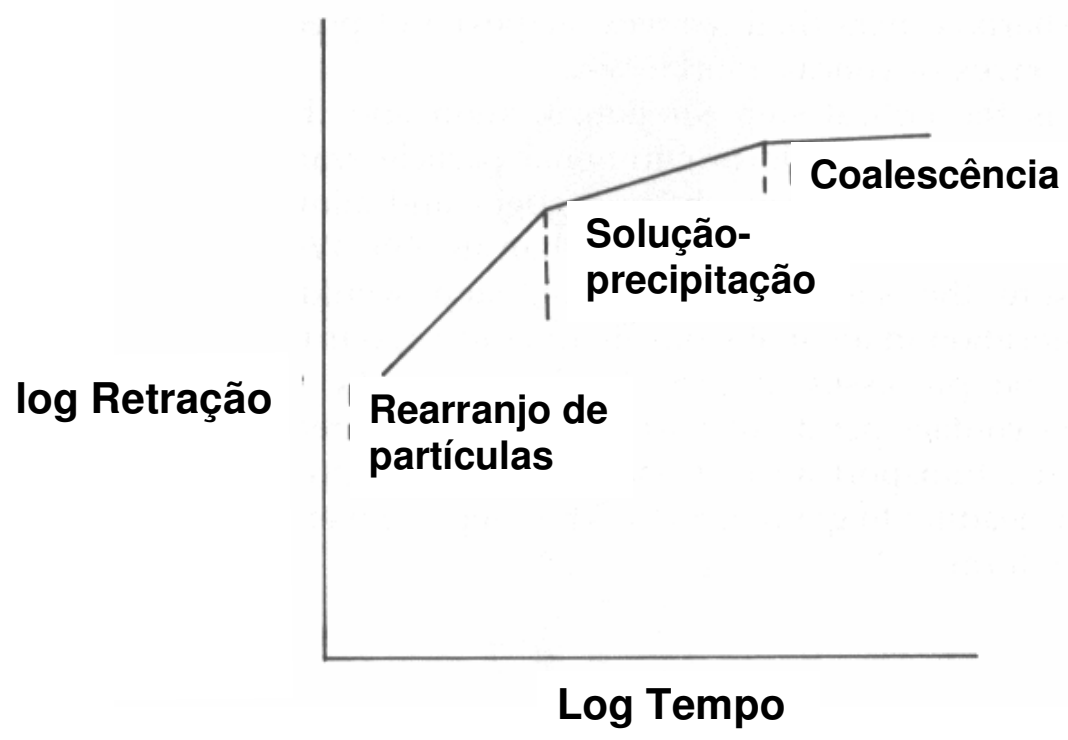

FIGURA 4 - Esquema de retração versus tempo de sinterização, na sinterização por fase líquida.

\section{Técnicas de Caracterização}

\section{Análise Térmica (Termogravimetria - TG) [38, 39]}

A análise térmica é definida como um grupo de métodos pelos quais as propriedades físicas ou químicas de uma substância ou de uma mistura são medidas em função da temperatura ou tempo, enquanto a amostra está sujeita a uma programação controlada de temperatura. O programa pode consistir em aquecer ou resfriar (dinâmico), ou manter a temperatura constante (isotérmica), ou qualquer seqüência destes.

A termogravimetria nos permite medir a variação de massa de uma substância em função da temperatura ou do tempo. Sendo assim, é um sistema com vasto campo de aplicação na caracterização do comportamento térmico dos materiais.

O instrumental básico da termogravimetria consiste numa balança de precisão acoplada a um forno que permite programar aumento de temperatura 
de forma linear com o tempo. A amostra é colocada em porta-amostra ou cadinho acoplado à balança. Os dados de massa gerados são captados pela saída serial do microcomputador. Um pequeno forno elétrico envolve o cadinho, de maneira que a temperatura da amostra pode ser controlada variando-se a potência do forno. Os resultados são apresentados sob forma de curva termogravimétrica (TG), na qual a variação de massa é registrada em função da temperatura ou do tempo; pode-se obter uma curva termogravimétrica derivada (DTG) onde a primeira derivada da curva TG é plotada em relação à temperatura ou tempo.

A termogravimetria diferencial é útil em algumas determinações complexas e qualquer mudança na taxa de perda ou ganho de massa pode ser prontamente identificada pelas inflexões que indicam reações consecutivas; portanto, mudanças de massa que ocorram a temperaturas próximas podem ser perfeitamente identificáveis.

Os resultados podem ser influenciados pelos seguintes fatores: efeitos instrumentais (taxa de aquecimento, atmosfera do forno, geometria do cadinho) e efeitos característicos da amostra (massa, tamanho, modo de preparação).

\section{Densidade [40]}

A densidade das cerâmicas é importante, pois define algumas propriedades do material. A densidade dos sólidos é determinada pela razão da massa com o volume do sólido. Em casos de estruturas cristalinas sem defeitos a densidade é denominada densidade cristalográfica ou densidade ideal.

$\mathrm{Na}$ determinação da densidade aparente, considera-se o volume dos sólidos incluindo defeitos e fases (poros). Em materiais compactados, a densidade aparente total pode ser medida pelo método geométrico ou pelo método de imersão (em um líquido não molhante ou recobrindo a amostra).

$\mathrm{Na}$ determinação da densidade aparente pelo método geométrico é necessário saber as dimensões da amostra e sua massa. Pode-se calcular a densidade através da equação:

$$
\mathrm{d}_{\mathrm{g}}=\mathrm{m} / \mathrm{V}
$$


onde: $d_{g}$ : é a densidade geométrica;

$\mathrm{m}$ : massa da amostra;

$\mathrm{V}$ : volume da amostra.

No método de determinação da densidade com líquido não molhante, utiliza-se um líquido com esta característica, para que não ocorra interação do líquido com a amostra, por exemplo o mercúrio, e o volume é determinado com o deslocamento do líquido quando a amostra é imersa no líquido. Pode-se também utilizar um líquido molhante, mas a amostra terá que ser recoberta por uma camada de uma substância tornando-a impermeável. Novamente é determinado o volume da amostra pelo deslocamento do líquido, mas nesse caso é necessário determinar a massa da substância que recobre a amostra e desconsiderá-la ao fazer o cálculo da densidade.

No método de imersão utiliza-se para o calculo da densidade a equação (3).

Em materiais sinterizados, a densidade aparente é obtida pelo método de imersão com líquido molhante, através do Princípio de Arquimedes (método hidrostático). Neste método, as amostras são imersas em um líquido inerte (água destilada) e aquecidas até próximo ao ponto de ebulição do líquido, por 2 h. Após o resfriamento ao ar, são realizadas as medidas de massa imersa e massa úmida. Em seguida é feita uma secagem em estufa. As amostras são resfriadas ao ar e novamente pesadas para a determinação da massa seca. Esses dados podem ser relacionados com a densidade do líquido utilizado na temperatura de medida de acordo com a equação:

$$
d_{H}=\left[\left(d_{L} \times M_{S}\right)-\left(d_{A R} \times M_{i}\right)\right] /\left(M_{U}-M_{I}\right)
$$

onde: $\mathrm{d}_{\mathrm{H}}$ densidade hidrostática ;

$\mathrm{M}_{\mathrm{S}}$ : massa seca;

$M_{\cup}$ : massa úmida;

$M_{\mathrm{i}}$ : massa imersa;

$\mathrm{d}_{\mathrm{L}}$ : densidade do líquido utilizado;

$\mathrm{d}_{\mathrm{AR}}$ : densidade do ar. 


\section{Microscopia Eletrônica de Varredura (MEV)}

A microscopia eletrônica compreende um conjunto de técnicas versáteis e capazes de fornecer informações sobre uma amostra em uma faixa de aumentos. De um lado, a microscopia óptica complementa a microscopia eletrônica de varredura com o estudo da textura, topografia e características da superfície de pós ou de peças sólidas. De outro lado, a microscopia eletrônica de alta resolução é capaz de fornecer informações em escala atômica [41].

O microscópio eletrônico de varredura é geralmente utilizado para observações de amostras espessas, ou seja, basicamente não transparentes a elétrons. Isso porque esta técnica apresenta uma alta resolução (até $3 \mathrm{~nm}$ ), uma grande profundidade de foco e permite obter imagens com aparência tridimensional.

As imagens no microscópio eletrônico de varredura são construídas ponto a ponto, de modo similar à formação de uma imagem de televisão. Para construir a imagem completa, o feixe de elétrons é varrido sobre uma área da superfície da amostra enquanto que um feixe no tubo de raios catódicos é varrido sincronicamente sobre um rastro geometricamente similar.

A interação do feixe de elétrons com a superfície da amostra resulta na emissão de elétrons e raios $X$ com uma faixa de distribuição de energia [42].

As interações podem ser divididas em espalhamento elástico, que afeta a trajetória dos elétrons na amostra sem alterar a energia cinética, responsável pelo fenômeno dos elétrons retroespalhados, e espalhamento não-elástico, que compreende as diferentes interações em que há perda de energia cinética dos elétrons secundários, Auger, raios $\mathrm{X}$ e catodoluminescência.

Cada um destes eventos fornece informações sobre a amostra. Os tipos de elétrons utilizados em microscopia eletrônica de varredura basicamente são os secundários e os retroespalhados. Os raios $X$ são utilizados para identificar e quantificar os elementos presentes [43].

O microscópio eletrônico de varredura pode possuir detetores diferentes para cada tipo de sinal, sendo que a resolução é limitada pelas características do equipamento e pelo processo de interação do feixe de elétrons com a amostra.

As interações analisadas são: a emissão de elétrons secundários e retroespalhados, que são utilizados para examinar características das amostras 
como topografia e composição. A topografia pode ser observada através da interação dos elétrons secundários, de energia menor que $50 \mathrm{eV}$, com a amostra. Variações localizadas do ângulo de inclinação da superfície, ou seja, a geometria da superfície causa variações na intensidade dos elétrons coletados. Os elétrons secundários têm origem na camada de valência e emergem da superfície da amostra, permitindo a visualização da topografia [42, 44].

A composição é observada em função da diferença de contraste de tons de cinza, relacionada com o número atômico dos elementos. O contraste é alto para baixos números atômicos e menos intenso para números atômicos mais elevados [44].

Amostras de materiais não condutores necessitam de uma camada condutora sobre a superfície para evitar efeitos de acúmulo de carga na superfície da amostra. Para isso, podem ser realizados recobrimentos com ouro, carbono ou ligas ouro-paládio. Para os recobrimentos com ouro ou ouropaládio é utilizada a técnica de deposição de íons ("sputtering"), na qual um alvo ( $\mathrm{Au}$ ou $\mathrm{Au}-\mathrm{Pd}$ ) é bombardeado com átomos de um gás como argônio, por exemplo, e átomos do metal são ejetados do alvo e depositados sobre a superfície da amostra. Geralmente são utilizadas pressões entre 0,1 e 0,05 mbar. A deposição de carbono é geralmente realizada por evaporação a partir de um alvo de grafita. Este tipo de recobrimento é especialmente indicado em microanálises por espectroscopia de energia dispersiva (EDS).

A microanálise eletrônica se baseia na medida de raios $X$ característicos. As linhas de raios $X$ característicos são específicas do número atômico da amostra e os seus comprimentos de onda (ou energia), através do qual, podese identificar o elemento que está emitindo radiação. O espectrômetro EDS trabalha sobre o princípio de que a energia de um fóton está relacionada com a freqüência da onda eletromagnética. O EDS possibilita a observação do espectro inteiro de raios $X$ de modo simultâneo, o que permite análise qualitativa rápida dos constituintes principais da amostra [42].

\section{Dilatometria}

A dilatometria é uma técnica de análise térmica utilizada para estudar a dependência entre a dilatação ou contração linear térmica dos materiais em 
função da temperatura. Esta técnica é muito útil no estudo do comportamento de materiais, como por exemplo, a transformação martensítica, a retração de uma cerâmica à verde durante o processo de sinterização, a temperatura de transição vítrea e a cinética de transformações de fase no estado sólido [45].

No dilatômetro, podem-se variar as taxas de aquecimento e resfriamento, assim como, trabalhar com diferentes atmosferas, tais como ar, vácuo, hidrogênio e atmosfera inerte.

A dilatometria é também muito utilizada no estudo da sinterização de materiais cerâmicos, onde ocorrem consideráveis variações de comprimento devido à densificação [43].

\section{Difração de Raios X}

A difratometria de raios $\mathrm{X}$ é uma técnica importante e útil no estudo dos materiais. Os métodos de difração são de grande importância na análise da estrutura cristalina. Esses métodos fornecem informação sobre a natureza do reticulado, assim como detalhes a respeito do tamanho, da perfeição e da orientação dos cristais.

Se um feixe de raios $X$ com uma dada freqüência incidir sobre um átomo isolado, elétrons deste átomo serão excitados e vibrarão com a freqüência do feixe incidente. Estes elétrons vibrando emitirão raios $X$ em todas as direções com a mesma freqüência do feixe incidente.

Quando a radiação incidente tiver comprimento de onda semelhante ao valor do espaçamento entre os átomos em um reticulado, ocorrerá interferência construtiva e interferência destrutiva.

Para que ocorra a difração (ou interferência construtiva) a lei de Bragg tem que ser satisfeita, ou seja, quando a distância extra percorrida pelos diversos feixes for um múltiplo inteiro de $\lambda$, como mostra a equação:

$$
\mathrm{n} \lambda=2 \mathrm{~d} \operatorname{sen} \theta
$$

onde

$\mathrm{n}$ : número inteiro de $\lambda$, também chamado de ordem da reflexão;

$\lambda$ : comprimento de onda da radiação; 
d: distância interplanar entre dois planos adjacentes;

$\theta$ : ângulo de incidência ou ângulo de Bragg.

As direções para as quais ocorre a difração são determinadas pela geometria do reticulado de Bravais.

Um dos métodos de difração de raios $X$ utilizado para o estudo de policristais é o método do pó, onde a radiação incidente é monocromática e o ângulo $\theta$ variável. $O$ difratômetro é um equipamento utilizado para a obtenção do perfil ou padrão de difração.

O padrão de difração é um conjunto de linhas ou picos, cada um com diferentes posições angulares e intensidades. A intensidade dos picos pode variar dependendo da preparação da amostra e das condições do equipamento. As posições angulares são fixas e características da amostra.

A identificação do padrão de difração provém de dados que vêm dos picos de difração com a consideração semiquantitativa da intensidade. Os ângulos difratados trazem informações relativas ao retículo cristalino, e as intensidades relativas trazem informações sobre a estrutura do cristal. Como a estrutura de um determinado composto é única, o seu padrão de difração também é único. Assim, o padrão de difração experimental é identificado por comparação, utilizando o arquivo JCPDS (Joint Committee on Powder Diffraction Standards).

\section{Espectroscopia Raman}

Várias técnicas permitem obter informações sobre a estrutura molecular, níveis de energia e as ligações químicas. A espectroscopia estuda a interação da radiação eletromagnética com a matéria, sendo um dos seus principais objetivos a determinação dos níveis de energia de átomos ou moléculas. No caso de moléculas, a região espectral onde estas transições são observadas depende do tipo de níveis envolvidos: eletrônicos, vibracionais ou rotacionais. Normalmente as transições eletrônicas estão situadas na região do ultravioleta ou visível, as vibracionais na região do infravermelho e as rotacionais na região de microondas. 
A interação da radiação eletromagnética com o movimento vibracional dos núcleos origina o espectro vibracional no infravermelho ou o espalhamento Raman. Uma maneira indireta de observar os espectros vibracionais, transferindo para a região do visível as informações que seriam normalmente obtidas no infravermelho, é através do espalhamento Raman, ou seja, do espalhamento inelástico da radiação eletromagnética monocromática que interage com as moléculas. As freqüências vibracionais são determinadas pela diferença entre as freqüências da radiação espalhada e a da radiação incidente.

No espalhamento Raman radiação, geralmente no visível ou ultravioleta, interage com a molécula e é espalhada com freqüência ligeiramente modificada. Esta variação de freqüência corresponde à diferença de energia entre dois estados vibracionais. Para que um modo vibracional seja ativo no espectro Raman é necessário que o momento de dipolo a ser considerado seja o induzido pela radiação eletromagnética, isto é, deve haver variação da polarizabilidade da molécula durante a vibração [46].

O espectro Raman é analisado pelo gráfico da intensidade de espalhamento (Raman) em função do número de onda. Visto que materiais inorgânicos tendem a ter espectro vibracional característico, os espectros Raman, podem ser usados com o propósito de identificação desses materiais através de sua composição. Para isto, faz-se necessário uma comparação do espectro Raman não conhecido com um espectro Raman de referência.

Além do possível uso na rotina de identificação de materiais, o espectro Raman pode ser usado para caracterizar sólidos, e fornecer informação estrutural. Com este propósito, é necessário um profundo conhecimento de espectro Raman do material estudado, e em particular, atribuir os picos a um modo de vibração. Métodos para esta atribuição são bastante complexos e de forma geral têm sido usados somente em estruturas de cristais simples [40].

Espectroscopia de Impedância

Existem diversas técnicas para a medida da condutividade elétrica em materiais, que podem ser divididas em técnicas ac e dc. Estas técnicas podem fazer uso de dois, três ou quatro terminais (ou pontas de prova). As técnicas ac 
podem ter freqüência fixa ou variável. A técnica de medida conhecida como espectroscopia de impedância é do tipo ac de freqüência variável.

As medidas de espectroscopia de impedância no estudo de eletrólitos sólidos foram inicialmente utilizadas por Bauerle em 1969 [47]. A representação dos resultados de impedância $(Z)$ é feita no plano complexo que resulta, no caso de eletrólito sólidos policristalinos, em semicírculos que descrevem as resistências e capacitâncias associadas aos fenômenos que ocorrem na amostra.

A medida é realizada formando-se uma célula composta pelo material em estudo e uma camada metálica em cada uma das faces (eletrodos), como mostrado na figura 5 .

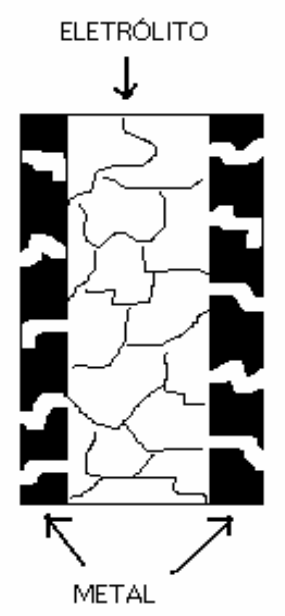

FIGURA 5 - Representação de uma célula eletroquímica composta pelo eletrólito sólido e pela camada de metal em cada uma das faces.

Um sinal elétrico é aplicado na amostra e a corrente resultante que passa pela célula é medida. A impedância da célula é calculada e o resultado é apresentado na forma de um diagrama, utilizado para determinar um circuito equivalente e determinar as propriedades elétricas do material.

Em coordenadas cartesianas a impedância pode ser representada, como sendo o vetor no plano complexo, figura 6.

O componente resistivo será representado no eixo real e o componente capacitivo no eixo imaginário.

$$
Z(\omega)=\operatorname{Re}(Z) \hat{\imath}+\operatorname{Im}(Z) \hat{\jmath}
$$


Utilizando a representação de Fresnel, a impedância pode ser re-escrita segundo a equação:

$$
Z(\omega)=Z^{\prime}+j \cdot Z^{\prime \prime}
$$

onde

$Z(\omega)$ : Impedância;

Z' : Componente real da impedância;

Z" : Componente imaginário da impedância.

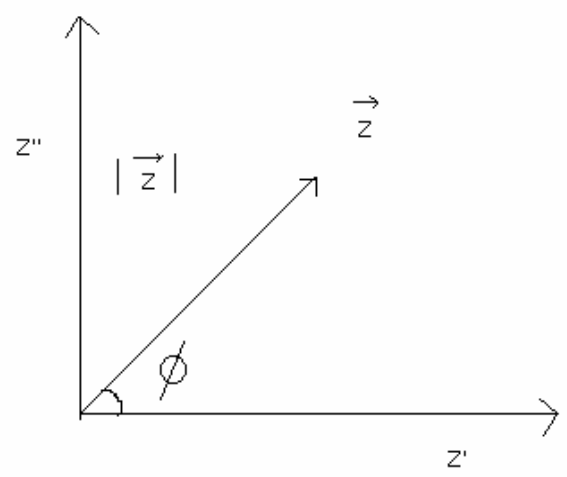

FIGURA 6 - Representação do vetor impedância no plano complexo.

Segundo Bauerle, o diagrama de impedância ideal de uma cerâmica policristalina condutora iônica, figura 7 , apresenta três semicírculos, sendo que o semicírculo de mais baixa freqüência representa a polarização do eletrodo; o semicírculo de freqüência intermediária representa a resistência do componente intergranular ou contorno de grão, e o semicírculo de freqüência mais elevada indica a resistência intragranular ou dos grãos da cerâmica [47]. 


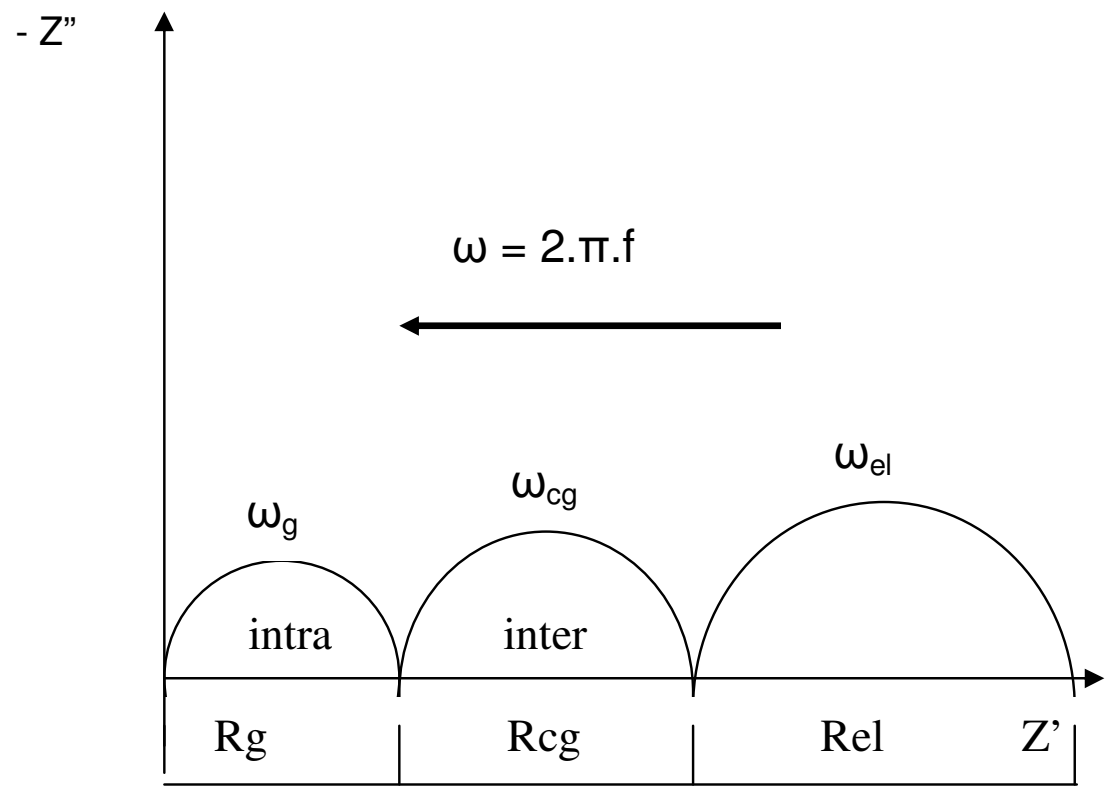

FIGURA 7 - Representação do diagrama de impedância. $R$ = resistência de cada um dos componentes ( $\mathrm{g}$ = grão; $\mathrm{cg}$ = contorno de grão e el = eletrodo), $\omega$ = freqüência angular, e a seta corresponde à direção do aumento da freqüência.

Com os valores de resistência de cada componente, obtidos no diagrama de impedância e conhecendo as dimensões das amostras, é calculada a resistividade elétrica segundo a equação:

$$
R=\rho .(L / S)
$$

onde

$\mathrm{R}$ : resistência;

$\rho$ : resistividade elétrica;

$L$ : espessura da amostra;

$S$ : área seccional. 
A técnica ac de espectroscopia de impedância mede a variação da resistência de uma amostra sólida em função da temperatura e da freqüência, ao contrário das demais técnicas de medida de resistividade, nas quais só há variação de temperatura. A principal vantagem desta técnica em relação às demais é que permite correlacionar aspectos da microestrutura com os componentes da resistividade total no eletrólito, isto acontece porque alguns aspectos da microestrutura possuem uma freqüência de relaxação característica. Como a medida da impedância é feita em função da freqüência, se dois aspectos microestruturas possuírem freqüências de relaxação distintas, eles poderão ser identificáveis no espectro resultante.

Quando essas freqüências não são suficientemente distintas, a sobreposição dos arcos de semicírculo se torna significativa e nesse caso é necessária a resolução numérica dos diagramas.

A resistividade elétrica de um eletrólito sólido varia em função da temperatura, de acordo com a equação de Arrhenius [48].

$$
\rho=\rho_{0} \exp (E / K T)=1 / \sigma
$$

onde

$\rho$ : resistividade;

$\rho_{0}:$ fator pré-exponencial da resistividade;

E : energia de ativação aparente para o processo;

$\mathrm{K}$ : constante de Boltzmann;

$\mathrm{T}$ : temperatura absoluta.

$\sigma:$ condutividade elétrica

Plotando um gráfico de $(\ln \rho)$ x $\left(10^{3} / \mathrm{T}\right)$ obtém-se um segmento de reta, com o qual, pelo coeficiente angular, calcula-se a energia de ativação térmica (E).

A condutividade elétrica total de um eletrólito sólido é a soma das contribuições de todos os portadores de carga presentes. Em compostos inorgânicos, a condutividade elétrica total é dada pela soma das condutividades eletrônica e iônica $[49,50]$. 
A dependência da condutividade elétrica total com a pressão parcial de oxigênio pode ser observada em alguns casos. Um estudo completo da condutividade elétrica de um óxido sólido inclui não somente a dependência da condutividade com a composição e temperatura, mas também com a pressão parcial de oxigênio [51].

Nos condutores predominantemente iônicos a condutividade independe da pressão parcial de $\mathrm{O}_{2}$, por outro lado, nos condutores eletrônicos e mistos a condutividade elétrica é função da pressão parcial de oxigênio. 


\section{3- MATERIAIS E MÉTODOS}

Neste capítulo serão descritos os materiais utilizados neste trabalho e os métodos empregados para a elaboração de amostras e sua caracterização.

\section{Materiais Precursores}

Os materiais precursores utilizados foram $\mathrm{ZrO}_{2}$ contendo $8 \% \mathrm{em}$ mol de $\mathrm{Y}_{2} \mathrm{O}_{3}$ (8YSZ, Tosoh Co.) e carbonato de cobalto (Alfa Aesar).

A tabela 3 mostra as especificações fornecidas pelo fabricante para 0 lote de 8YSZ utilizado neste trabalho.

TABELA 3 - Teores de impurezas e características físicas da zircônia estabilizada com ítria, fornecidos pelo fabricante.

\begin{tabular}{cc}
\hline Impureza & Valor (\% em massa) \\
\hline $\mathrm{Y}_{2} \mathrm{O}_{3}$ & 13,23 \\
$\mathrm{Al}_{2} \mathrm{O}_{3}$ & Máx. 0,005 \\
$\mathrm{SiO}_{2}$ & Máx. 0,002 \\
$\mathrm{Fe}_{2} \mathrm{O}_{3}$ & 0,003 \\
$\mathrm{Na}_{2} \mathrm{O}$ & 0,071 \\
\hline Característica & Valores \\
\hline Perda ao fogo & 0,71 \\
(\% em massa) & \\
Densidade (g/cm $\left.{ }^{3}\right)$ & 5,9 \\
Área de Superfície & 13,1 \\
Específica (m²/g) & \\
Tamanho de Cristalito $(\AA)$ & 250 \\
\hline
\end{tabular}


As principais características do carbonato de cobalto $\left(\mathrm{CoCO}_{3}\right)$, fornecidas pelo fabricante são: pureza 99\%; cor violeta; massa molecular igual a 118,94 e densidade igual a $4,16 \mathrm{~g} / \mathrm{cm}^{3}$.

\section{Elaboração de Corpos de Prova}

A técnica utilizada para a elaboração dos corpos de prova foi a mistura de pós precursores, seguida de reação no estado sólido.

Foram preparadas diversas composições de acordo com a estequiometria $8 Y S Z+x \%$ em mol de Co, com $x=0 ; 0,025 ; 0,05 ; 0,1 ; 0,25$; 0,5; 1,0; 2,0; 3,0; 4,0; 5,0; 7,5 e 10,0. É importante ressaltar que os cálculos foram feitos com base na concentração molar do metal (Co).

Para a mistura de pós precursores, quantidades estequiométricas de $8 Y S Z$ e $\mathrm{CoCO}_{3}$ foram pesadas em uma balança analítica (Mettler, H315), seguida de homogeneização feita em misturador mecânico (Túrbula, modelo T2C) durante 1 hora (figura 8).

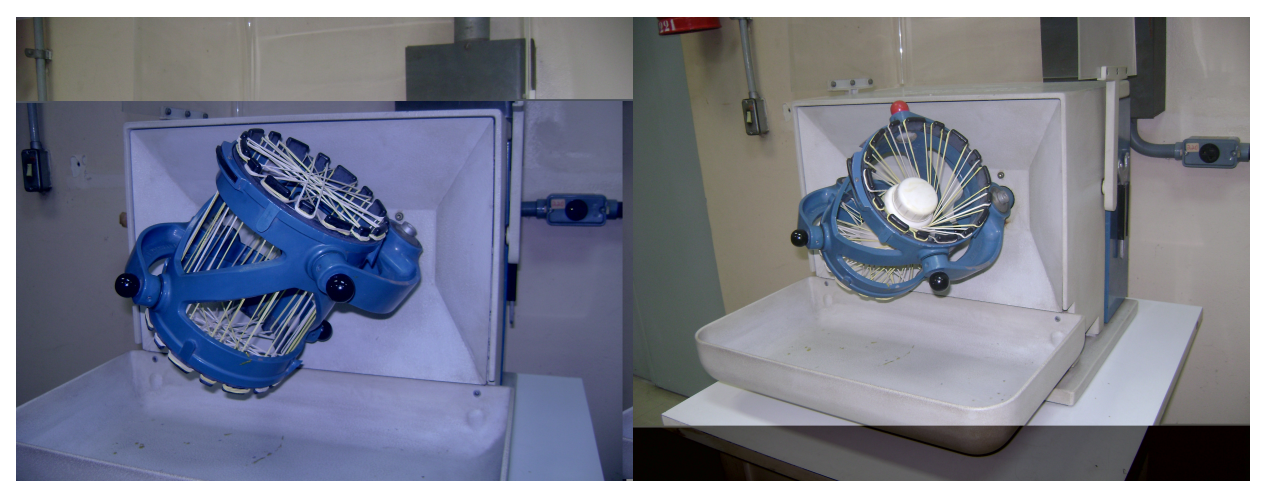

FIGURA 8 - Fotos do misturador mecânico (Túrbula, modelo T2C), utilizado no processo de homogeneização.

No processo de homogeneização foram utilizados meios de moagem de $\mathrm{ZrO}_{2}$ em meio líquido (álcool isopropílico). Depois de seco, o pó obtido foi desaglomerado em almofariz de ágata. Corpos de prova foram conformados em forma de cilindros por compactação uniaxial em matriz de aço inoxidável, 
com diâmetro de $10 \mathrm{~mm}$ e espessura de 1 a $2 \mathrm{~mm}$, com pressão aproximadamente de $100 \mathrm{MPa}$. A lubrificação da matriz foi feita com ácido esteárico.

Em geral, nos processos de mistura de dois ou mais componentes onde um deles está na forma de sal, é comum realizar a sua decomposição térmica numa etapa anterior à sinterização. Assim, para verificar a necessidade deste procedimento foram preparadas amostras com e sem a etapa de decomposição térmica (650 ำ / 1 h), e as densidades geométrica e hidrostática das amostras sinterizadas a $1300 \stackrel{\circ}{\circ} / 0,5 \mathrm{~h}$, foram comparadas, tabela 6.

TABELA 4 - Valores de densidades geométrica e hidrostática das amostras $8 Y S Z+0,5 \% \mathrm{~mol} \mathrm{Co}$, sinterizadas a $1300^{\circ} \mathrm{C} / 1 \mathrm{~h}$. Erro estimado igual a 0,05 g/ $\mathrm{cm}^{3}$.

\begin{tabular}{ccc}
\hline $\begin{array}{c}\text { Amostra: } \mathbf{8 Y S Z}+\mathbf{0 , 5} \% \\
\text { mol Co }\end{array}$ & $\begin{array}{c}\text { Densidade } \\
\text { Geométrica } \\
\left(\mathbf{g} / \mathbf{~ c m}^{3}\right)\end{array}$ & $\begin{array}{c}\text { Densidade } \\
\text { Hidrostática } \\
\left(\mathbf{g} / \mathbf{~ c m}^{3}\right)\end{array}$ \\
\hline Calcinado & 5,87 & 5,86 \\
Não calcinado & 6,06 & 5,84 \\
\hline
\end{tabular}

Comparando os valores de densidade hidrostática, não foi observada uma variação significativa. Sendo assim, não foi realizada a calcinação prévia das amostras.

Os corpos de prova foram sinterizados em um forno resistivo (Lindberg Blue $\mathrm{M}$ ), tipo caixa, com taxa de aquecimento e resfriamento de $10 \stackrel{\circ}{\circ} / \mathrm{min}$. $\mathrm{A}$ sinterização foi feita em temperaturas de patamar de 1200,1300 e $1400{ }^{\circ} \mathrm{C}$ e tempos de patamar de 0,1 e 0,5 h.

A figura 9 mostra a seqüência experimental, utilizada para a mistura dos pós precursores e elaboração dos corpos de prova descrita acima. 


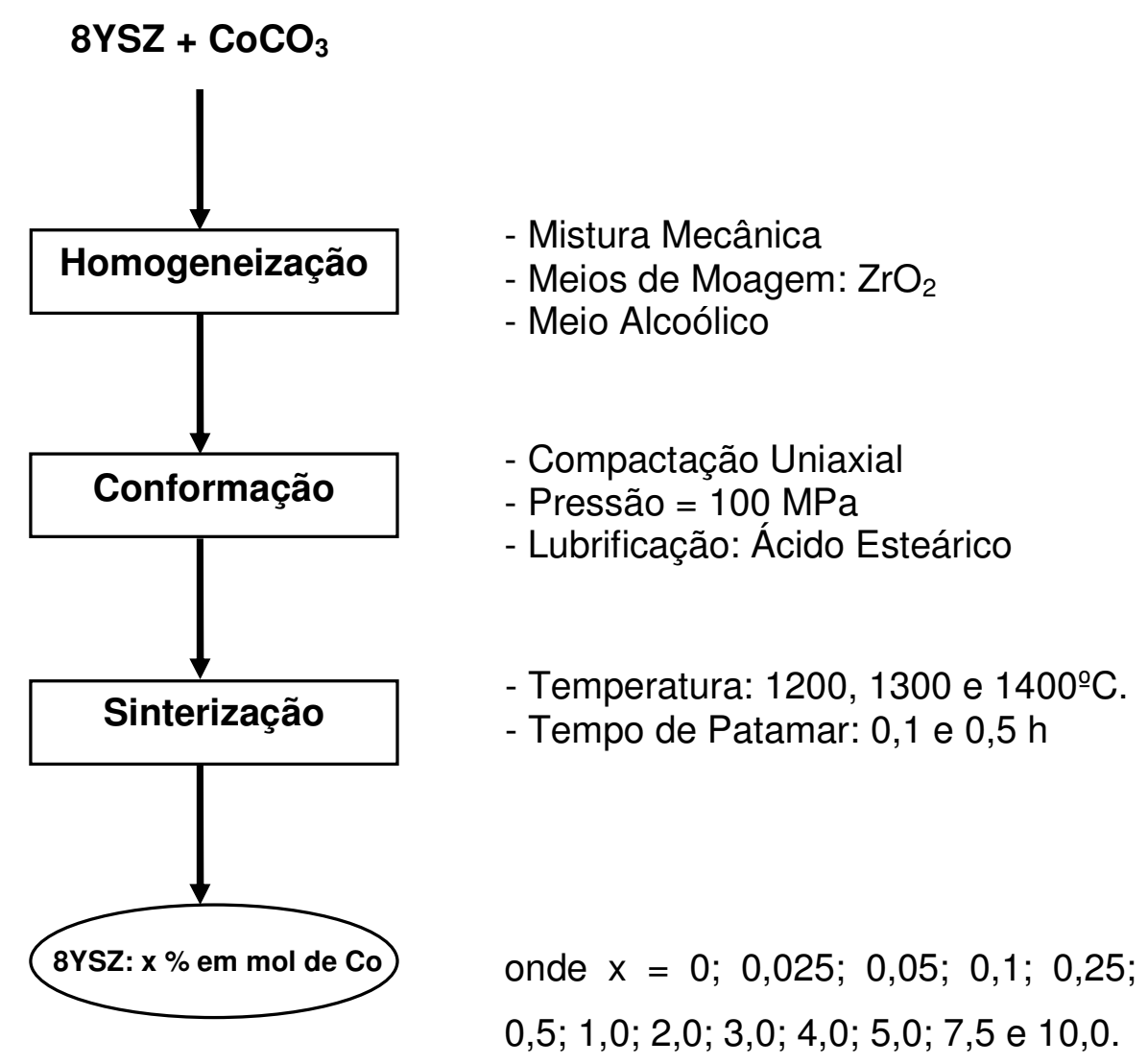

FIGURA 9 - Diagrama de blocos da metodologia utilizada para a mistura dos pós precursores e elaboração dos corpos de prova.

\section{Técnicas de Caracterização}

\section{Análise Térmica (Termogravimetria - TG)}

A termogravimetria (TG) foi utilizada para analisar a decomposição do carbonato de cobalto. A análise foi realizada numa termobalança (Shimadzu, TGA-50) do laboratório de corrosão - CCTM/ IPEN.

$\mathrm{Na}$ análise termogravimétrica o porta-amostra é zerado e a amostra é transferida para um pequeno cadinho de platina. Sua massa é medida logo que o sistema esteja estabilizado. O aquecimento é iniciado e atinge $900 \stackrel{\circ}{\circ}$ gradativamente, sob atmosfera dinâmica de ar sintético, com um fluxo de 15 $\mathrm{mL} / \mathrm{min}$, com razão de aquecimento de $10 \stackrel{\circ}{\circ}$ / min e massa de amostra em 
torno de $8,4 \mathrm{mg}$. As variações na massa são medidas e registradas em um computador com programa de coletas de dados.

\section{$\underline{\text { Densidade }}$}

As medidas de densidade aparente dos corpos de prova foram feitas pelo método geométrico e pelo método hidrostático (Principio de Arquimedes).

Para o método geométrico, foram medidas as massas e as dimensões, comprimento e diâmetro, das amostras sinterizadas. Para as medidas de dimensões, foi utilizado um micrômetro Tesa (precisão $=0,001 \mathrm{~mm}$ ) e uma balança analítica (Mettler, H315, precisão= 0,1 mg). Foram feitas 10 medidas de massa e 10 medidas de dimensões (diâmetro e espessura).

No método hidrostático, as amostras foram fervidas em água destilada por 2 h. Após o resfriamento, foram medidas as massas imersa e úmida. Em seguida as amostras foram secas em uma estufa (Fanem $315 \mathrm{SE}$ ) a $100{ }^{\circ} \mathrm{C}$, resfriadas, e foi feita a medida da massa seca. Para as medidas de massas foram feitas 10 pesagens para cada amostra. Com esses dados e com o valor da densidade da água e do ar na temperatura de medida, foi calculada a densidade, através da equação (4). Para as medidas de massa imersa, úmida e seca, foi utilizada uma balança analítica (Mettler, H315). Para os valores de densidades, foi estimado um erro de $\pm 0,05$.

\section{Microscopia Eletrônica de Varredura}

Observou-se a forma e o tamanho das partículas e/ou aglomerados de partículas nos pós. Para esta observação, uma quantidade de pó foi depositada sobre um porta-amostra com o auxílio de fita adesiva e recoberto com ouro por "sputtering". Para algumas amostras na forma de pó, foram feitas análises por espectroscopia de raios $\mathrm{X}$ por energia dispersiva (EDS).

Para a observação de alguns aspectos da microestrutura, as amostras sinterizadas foram fraturadas e fixadas sobre um porta-amostra com o auxílio de cola de prata. Após a secagem, as amostras foram recobertas por um filme de ouro por sputtering. As imagens foram feitas na face previamente fraturada, sem qualquer tratamento térmico ou químico.

Para a determinação do tamanho de grão, as amostras foram seccionadas transversalmente, utilizando uma cortadora (Isomet, Buehler) a 
disco (adiamantado). Após o corte, as amostras foram embutidas em resina pelo processo de embutimento a frio. Em seguida as amostras foram polidas em uma politriz (Panambra, DP9U), utilizando pasta adiamantada de 6 e $1 \mu \mathrm{m}$. Após o polimento as amostras foram desembutidas, pelo processo de aquecimento da resina e sobre a superfície seccionada foi feito um ataque térmico num forno tubular (Lindberg). Esse ataque foi realizado a temperatura $100 \stackrel{\circ}{ } \mathrm{C}$ abaixo da temperatura de patamar utilizado na sinterização, por um tempo de $45 \mathrm{~min}$. $O$ ataque térmico é utilizado para que os contornos de grão sejam revelados.

Após 0 ataque térmico as amostras foram fixadas sobre um portaamostra com auxílio de uma "cola" de prata e recobertas com filme de ouro por sputtering.

Para a determinação do tamanho do grão, foi utilizado o método Mendelson [52] ou método dos interceptos. A equação para determinação de grãos é dada por:

$$
\mathrm{G}=1,56 . \overline{\mathrm{e}}
$$

onde:

$\mathrm{G}=$ tamanho médio de grãos;

$\overline{\mathrm{e}}=$ distancia média dos interceptos

As micrografias e as análises de EDS foram obtidas em um microscópio eletrônico de varredura (Phillips, XL 30).

\section{Dilatometria}

Para análise da retração linear, corpos de provas foram compactados uniaxialmente na forma de cilindros, em uma matriz de aço inoxidável com diâmetro de $5 \mathrm{~mm}$ e espessura de $8 \mathrm{~mm}$. As medidas de retração linear foram feitas da temperatura ambiente até $1400{ }^{\circ} \mathrm{C}$, com taxa de aquecimento de $10^{\circ} \mathrm{C} / \mathrm{min}$. Para esta análise, foi utilizado um dilatômetro (Setaram, modelo Labsys), do laboratório de células a combustível - PROCEL / IPEN). 


\section{Difração de Raios X}

A caracterização estrutural das amostras foi feita por difração de raios $X$. As amostras foram compactadas uniaxialmente na forma de pastilhas e sinterizadas a 1200 e $1300{ }^{\circ} \mathrm{C}$, com tempo de patamar de 0,5 h. Para esta análise, foi utilizado um difratômetro de raios X (Bruker - AXS, D8 Advance), com radiação $\mathrm{Cu} \mathrm{K}_{\alpha}$, no intervalo angular de $20^{\circ}$ a $80^{\circ}(2 \theta)$, com varredura de 0 , 05 / 3 s. Para indexação das fases cristalinas foram utilizados os arquivos Joint Commitee on Powder Diffraction Standards - JCPDS.

\section{Espectroscopia Raman}

Complementação da análise estrutural foi obtida com a espectroscopia Raman. Utilizou-se um espectrômetro Renishaw Raman Microscope System 3000, acoplado a um microscópio Olympus BH - 2 e a um detector CCD (Wright, $600 \times 400$ pixels) resfriado por Peltier, do laboratório de Espectroscopia Molecular do Instituto de Química da Universidade de São Paulo (Fapesp no 94/5929-5). Para esta medida foi utilizada radiação excitante de 632,8 nm de um laser de He-Ne. As amostras para esta análise foram preparadas na forma de pastilha por compactação uniaxial e sinterizadas a $1300{ }^{\circ} \mathrm{C}$, com tempo de patamar de $0,5 \mathrm{~h}$. Neste caso, os espectros obtidos foram analisados de forma comparativa aos dados da literatura.

\section{Espectroscopia de Impedância}

Amostras em forma de pastilhas e sinterizadas a $1300{ }^{\circ} \mathrm{C}$ e $1400{ }^{\circ} \mathrm{C}$, com tempos de patamar de 0,1 e $0,5 \mathrm{~h}$, foram caracterizadas por espectroscopia de impedância. As medidas foram feitas na faixa de freqüência de $5 \mathrm{~Hz}$ a $13 \mathrm{MHz}$, com tensão aplicada de $100 \mathrm{mV}$ e intervalo de temperatura de 200 a $500 \stackrel{\circ}{ } \mathrm{C}$. Como material de eletrodo foi aplicada prata nas superfícies das amostras, seguido de tratamento térmico a $400 \stackrel{\circ}{\circ}$, para fixação das partículas metálicas e eliminação da resina. Para esta análise, utilizou-se um analisador de impedância Hewlett Packard 4192A (FAPESP no 92/0296-2), conectado via HPIB, a um controlador HP serie 900 . Foi utilizada uma câmara porta-amostra em inconel 600 (figuras 10 e 11), que possibilita a medida de 3 amostras por ciclo. 


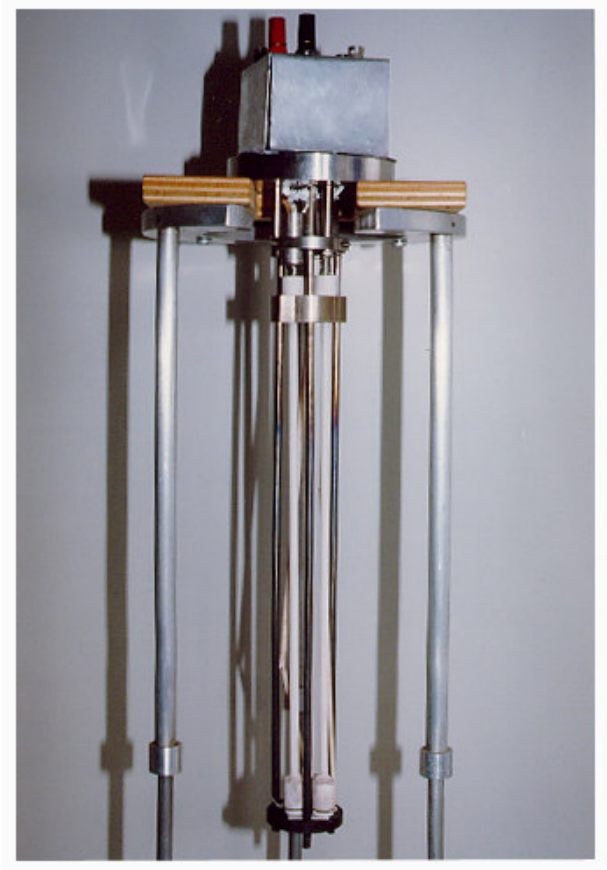

FIGURA 10 - Foto da câmara de medidas elétricas para até três amostras.

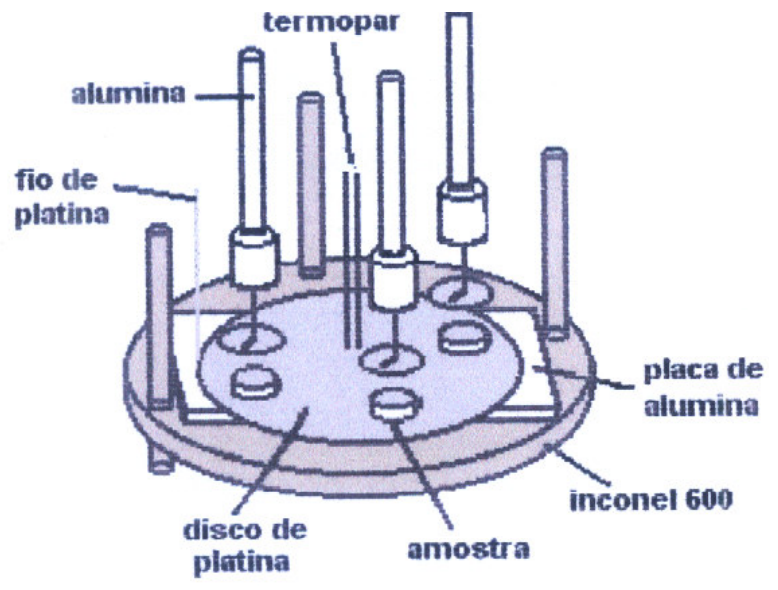

FIGURA 11 - Desenho esquemático do porta-amostra utilizado para as medidas de espectroscopia de impedância.

Os dados coletados foram analisados por programa computacional específico [53]. Para esta análise não foi considerado o efeito de porosidade. 


\section{4 - RESULTADOS E DISCUSSÃO}

Neste capítulo serão discutidos os principais resultados obtidos do material particulado, dos compactos a verde e do material sinterizado.

Para um melhor entendimento do processo de decomposição do carbonato de cobalto, foi feita a análise termogravimétrica, TG, e o resultado é mostrado na figura 12. A perda de massa ocorre em duas etapas. A primeira etapa se estende até $~ 370{ }^{\circ} \mathrm{C}$, mas com diversas taxas de perda de massa. Desde a temperatura ambiente até $\sim 200{ }^{\circ} \mathrm{C}$ a perda de massa é contínua e chega a $\sim 10 \%$. Entre $\sim 200{ }^{\circ} \mathrm{C}$ e $\sim 280{ }^{\circ} \mathrm{C}$ a perda de massa $(\sim 22 \%)$ é acentuada, enquanto que entre $\sim 270{ }^{\circ} \mathrm{C}$ e $370 \stackrel{\circ}{\circ} \mathrm{C}$ é lenta e chega a $\sim 18 \%$. Assim, nessa primeira etapa, a perda total de massa atinge 33,8\%. Entre $~ 370$ ${ }^{\circ} \mathrm{C}$ e $825{ }^{\circ} \mathrm{C}$ não há variação de massa. Ocorre nova perda de massa $(\sim 6,6 \%)$ entre $825 \stackrel{\circ}{\circ} \mathrm{C}$ e $870 \stackrel{\circ}{\circ}$. Desta forma, assumindo que os produtos de decomposição detectados neste trabalho são os mesmos que aqueles reportados na referência [el], a decomposição térmica do carbonato de cobalto utilizado neste trabalho ocorre de acordo com as seguintes reações:

entre temperatura ambiente $\mathrm{e} \sim 370^{\circ} \mathrm{C}$ :

$$
3 \mathrm{CoCO}_{3} \longrightarrow \mathrm{Co}_{3} \mathrm{O}_{4}+2 \mathrm{CO}_{2}+\mathrm{CO}
$$

entre $\sim 825^{\circ} \mathrm{C}$ e $\sim 870{ }^{\circ} \mathrm{C}:$

$$
\mathrm{Co}_{3} \mathrm{O}_{4} \longrightarrow 3 \mathrm{CoO}+1 / 2 \mathrm{O}_{2}
$$

Com perdas de massa teóricas iguais a 32,5\%, equação (11) e 6,7\%, equação (12). A diferença entre as perdas de massa teórica e experimental na primeira etapa do processo de decomposição é devido à umidade ( 1,3\%). 


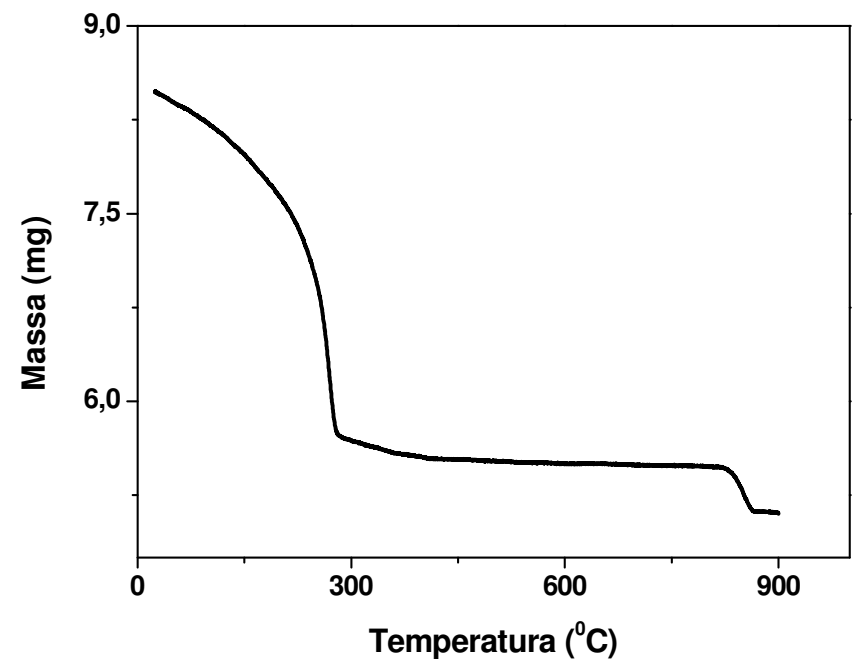

FIGURA 12 - Curva termogravimétrica (TG) do carbonato de cobalto.

A figura 13 apresenta uma micrografia obtida em microscópio eletrônico de varredura da amostra 8YSZ. A zircônia estabilizada com $8 \% \mathrm{~mol}$ de ítria (8YSZ) é preparada por co-precipitação, sendo que na etapa final é feita a nebulização ("spray drying") para a obtenção de grânulos. A figura mostra a forma e o tamanho dos grânulos, que têm formato esférico, com distribuição de tamanho que vai de $\sim 25$ a $50 \mu \mathrm{m}$.

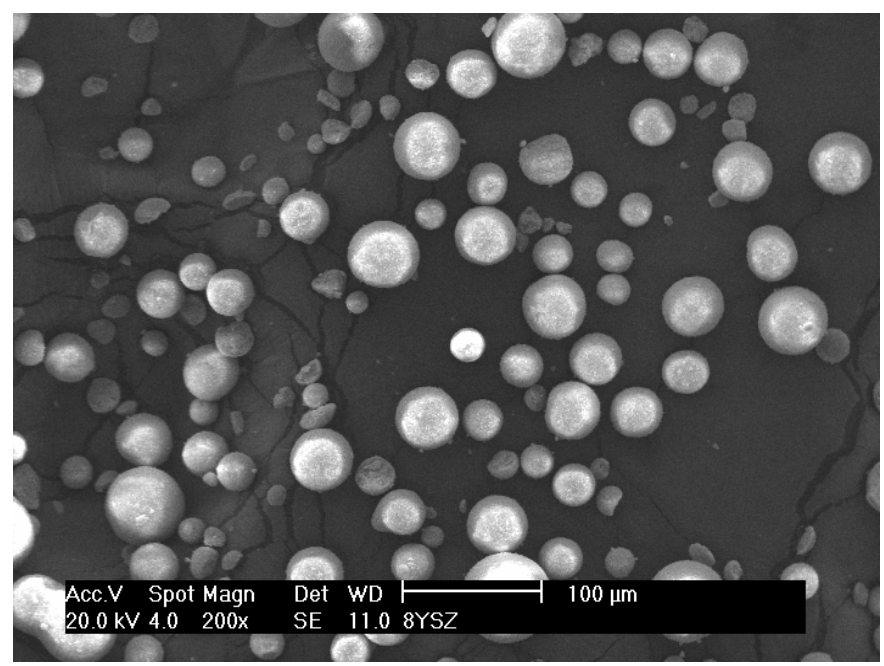

FIGURA 13 - Micrografia obtida em microscópio eletrônico de varredura do pó precursor $8 Y S Z$. 
A figura 14 mostra micrografias obtidas em microscópio eletrônico de varredura da 8YSZ contendo 1,0; 5,0 e 10,0\% mol Co, respectivamente, após homogeneização por $1 \mathrm{~h}$ em misturador mecânico.
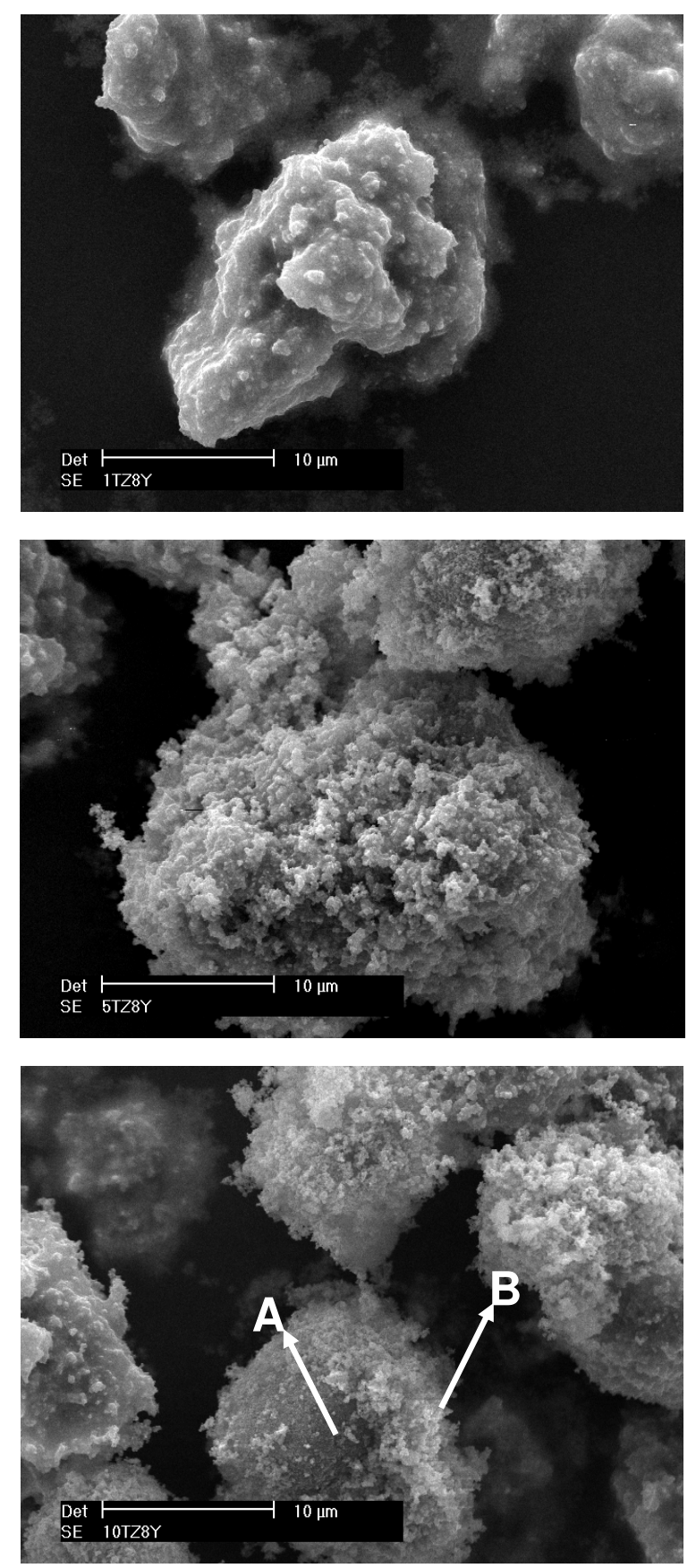

FIGURA 14: Micrografia obtida em microscópio eletrônico de varredura da mistura $8 Y S Z+1,0 \%$ mol Co (superior), $8 Y S Z+5,0 \%$ mol Co (centro), $8 Y S Z+$ $10,0 \%$ mol Co (inferior). 
Como pode ser visto, o processo de mistura incorreu na formação de aglomerados de tamanhos relativamente grandes $(\geq 10 \mu \mathrm{m})$. Na micrografia da mistura $8 Y S Z+10,0 \% \mathrm{~mol}$ Co (inferior), figura 14 , é observado que nos aglomerados são identificadas regiões mais escuras, (A), e regiões mais claras, (B). Essas regiões foram analisadas por EDS e o resultado é mostrado nas figuras 15 e 16.

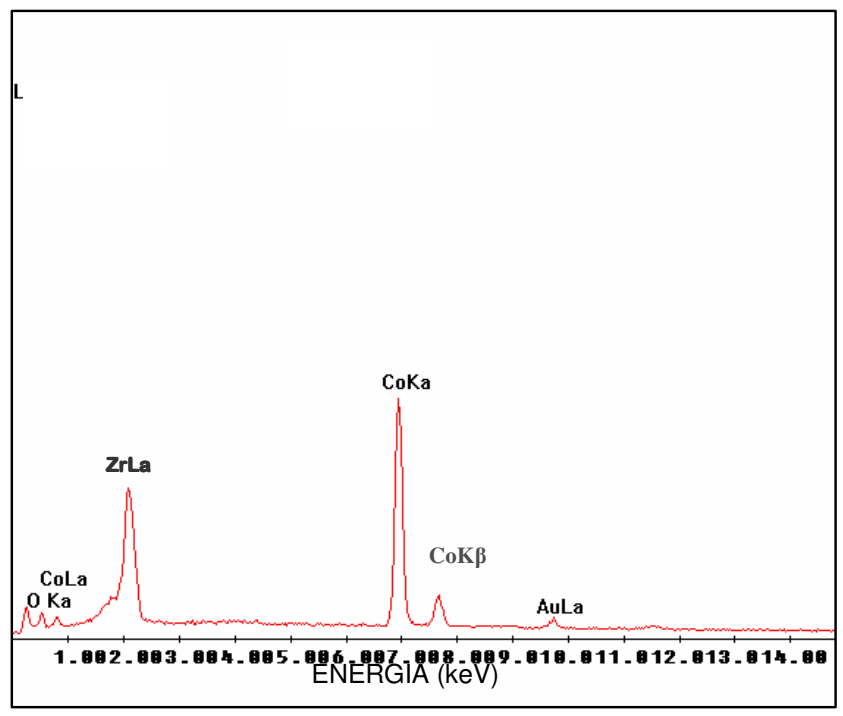

FIGURA 15: Espectro de raios $X$ por energia dispersiva da região mais escura, (A), do aglomerado de $8 \mathrm{YSZ}+10,0 \% \mathrm{~mol}$ Co.

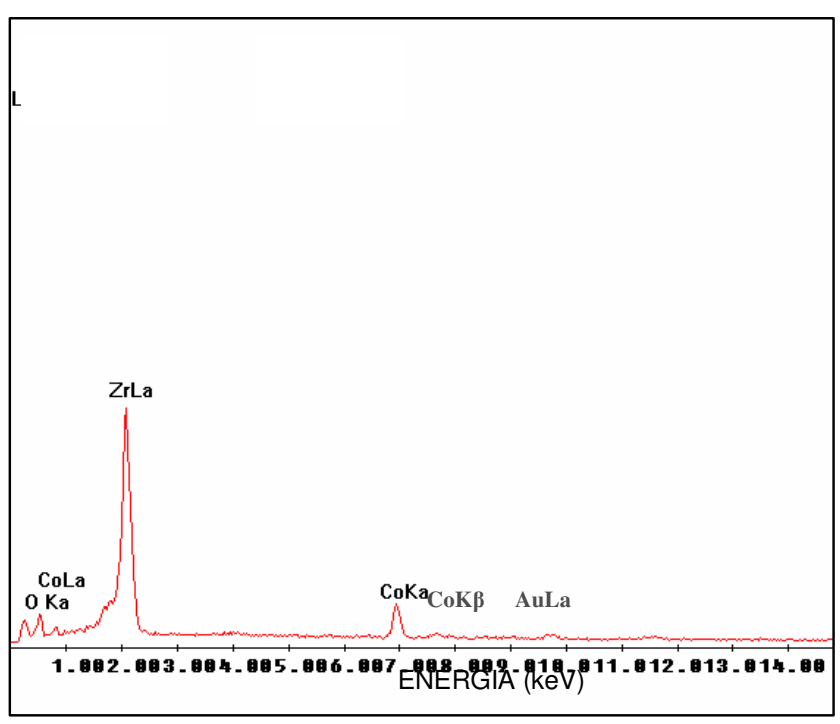

FIGURA 16: Espectro de raios $X$ por energia dispersiva da região mais clara, (B), do aglomerado de $8 \mathrm{YSZ}+10,0 \% \mathrm{~mol}$ Co. 
O espectro de EDS de uma região mais escura (figura 15 correspondendo a região A na figura 14) evidencia uma alta concentração de Co quando comparada ao $\mathrm{Zr}$, mostrando que as regiões mais escuras, referemse ao Co não disperso homogeneamente na matriz de zircônia.

A análise de EDS de uma das regiões mais claras (figura 16 correspondendo a região $B$ na figura 14) mostra que neste caso, os picos do $\mathrm{Zr}$ (maior intensidade) e do Co, evidenciam regiões onde a mistura dos dois componentes foi homogeneizada satisfatoriamente.

Para uma melhor análise, a tabela 4, apresenta os valores de energia de emissão fluorescente de cada elemento.

TABELA 5 - Valores de energia de raios X característicos dos diversos elementos.

\begin{tabular}{cc}
\hline Elemento químico & Energia (keV) \\
\hline Zircônio $(\mathrm{L} \boldsymbol{\alpha})$ & 2,04 \\
Cobalto $(\mathrm{K} \boldsymbol{\alpha})$ & 6,92 \\
Cobalto $(\mathrm{K} \boldsymbol{\beta})$ & 7,64 \\
Ítrio & 1,92 \\
Oxigênio $(\mathrm{K} \boldsymbol{\alpha})$ & 0,51 \\
\hline
\end{tabular}

As energias, na tabela 4, correspondem aos elementos químicos encontrados no EDS da mistura do pó analisado, 8YSZ contendo 10,0\% mol Co. Este resultado comprova que o processo de mistura conduz a baixa homogeneidade química, principalmente com a adição de dopantes em pequenas quantidades [54]. Apesar de ser esperado uma melhor homogeneização na sinterização pela difusão dos cátions na solução sólida.

A seguir, foram feitas caracterizações dos compactos a verde, e foram escolhidas amostras $8 Y S Z+x \%$ mol Co com $x=0 ; 0,1 ; 0,25 ; 0,5$ e 1,0. Estas amostras foram caracterizadas por dilatometria.

Os resultados de retração linear obtidos para compactos são mostrados na figura 17, e os valores de temperatura de início da retração e de temperatura na qual a retração é máxima, são mostrados na Tabela 5. 


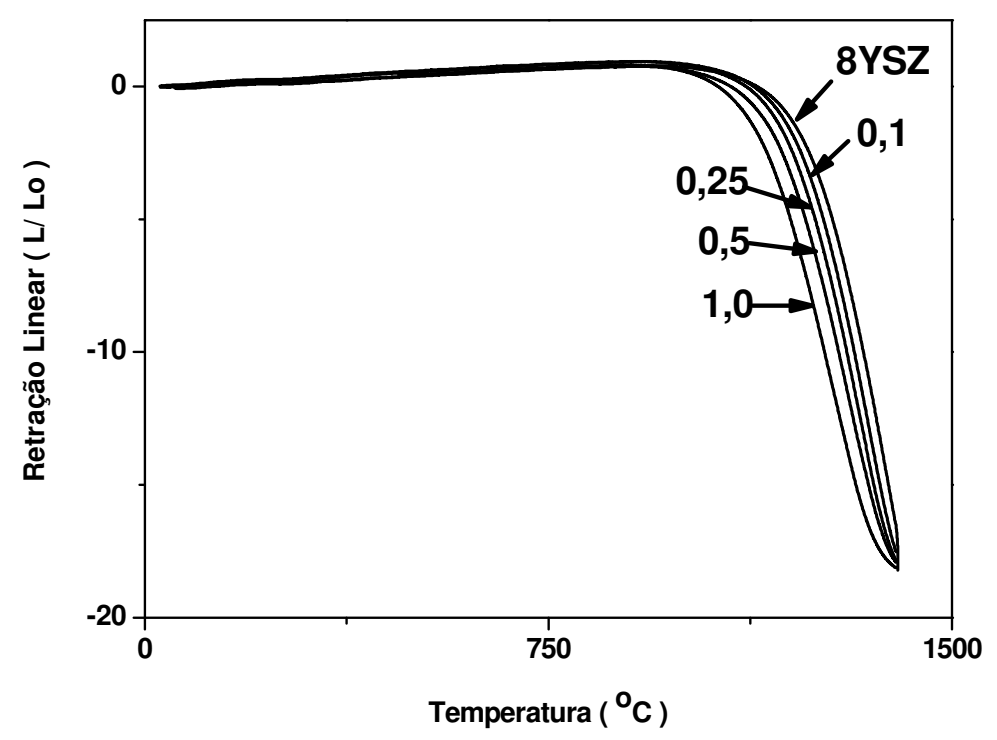

FIGURA 17 - Curvas de retração linear em função da temperatura das amostras $8 Y S Z+x \%$ mol Co, onde $x=0 ; 0,1 ; 0,25 ; 0,5$ e 1,0.

TABELA 6 - Valores de temperatura de início da retração e da temperatura na qual a taxa de retração é máxima, obtidos das curvas de retração linear das amostras $8 \mathrm{YSZ}+\mathrm{x} \% \mathrm{~mol}$ Co, com $\mathrm{x}=0 ; 0,1 ; 0,25 ; 0,5$ e 1,0 .

\begin{tabular}{ccc}
\hline $\begin{array}{c}\text { Teor de Co } \\
(\% \text { mol })\end{array}$ & $\begin{array}{c}\text { T. início da retração } \\
\left({ }^{0} \mathbf{C}\right)\end{array}$ & $\begin{array}{c}\text { T. máxima retração } \\
\left({ }^{0} \mathbf{C}\right)\end{array}$ \\
\hline 0 & 1208 & 1377 \\
0,1 & 1210 & 1345 \\
0,25 & 1186 & 1333 \\
0,5 & 1157 & 1309 \\
1,0 & 1115 & 1272 \\
\hline
\end{tabular}

Os resultados da figura 17 e da Tabela 5 mostram que aumentando o teor de Co adicionado à $8 Y S Z$ há redução gradativa na temperatura de início da retração. Assim, por exemplo, 1,0\% mol Co reduz a temperatura de início da retração por $100 \stackrel{\circ}{ } \mathrm{C}$. A temperatura na qual a retração é máxima também diminui correspondentemente. Entretanto, como mostram as curvas da figura 17, para a temperatura de $1400{ }^{\circ} \mathrm{C}$ ainda ocorre retração nos compactos. Isto mostra que para reduzir de forma significativa a temperatura de sinterização na zircônia estabilizada com ítria seria necessário um teor mais elevado do aditivo, 
o que poderia comprometer outras propriedades do eletrólito sólido.

Na referência [32], onde foi utilizada matriz de zircônia estabilizada com 8\% em mol de ítria foi mostrado que a adição de Co promoveu maior retração que aquela obtida neste trabalho. Uma explicação possível para essa divergência é a forma como o Co foi adicionado (nitrato, carbonato, etc.). Além disso, algumas das etapas de processamento pré-sinterização podem produzir profundas modificações no comportamento dos materiais. Sendo que os autores revelam que a medida da retração linear foi feita ao ar, enquanto que neste trabalho esta medida foi realizada em atmosfera inerte.

A figura 18 mostra micrografias de superfícies de fratura de amostras $8 Y S Z, 8 Y S Z+5,0 \%$ e $8 Y S Z+10,0 \%$ mol Co, sinterizadas a $1300 \stackrel{\circ}{\circ} / 0,5 \mathrm{~h}$. 

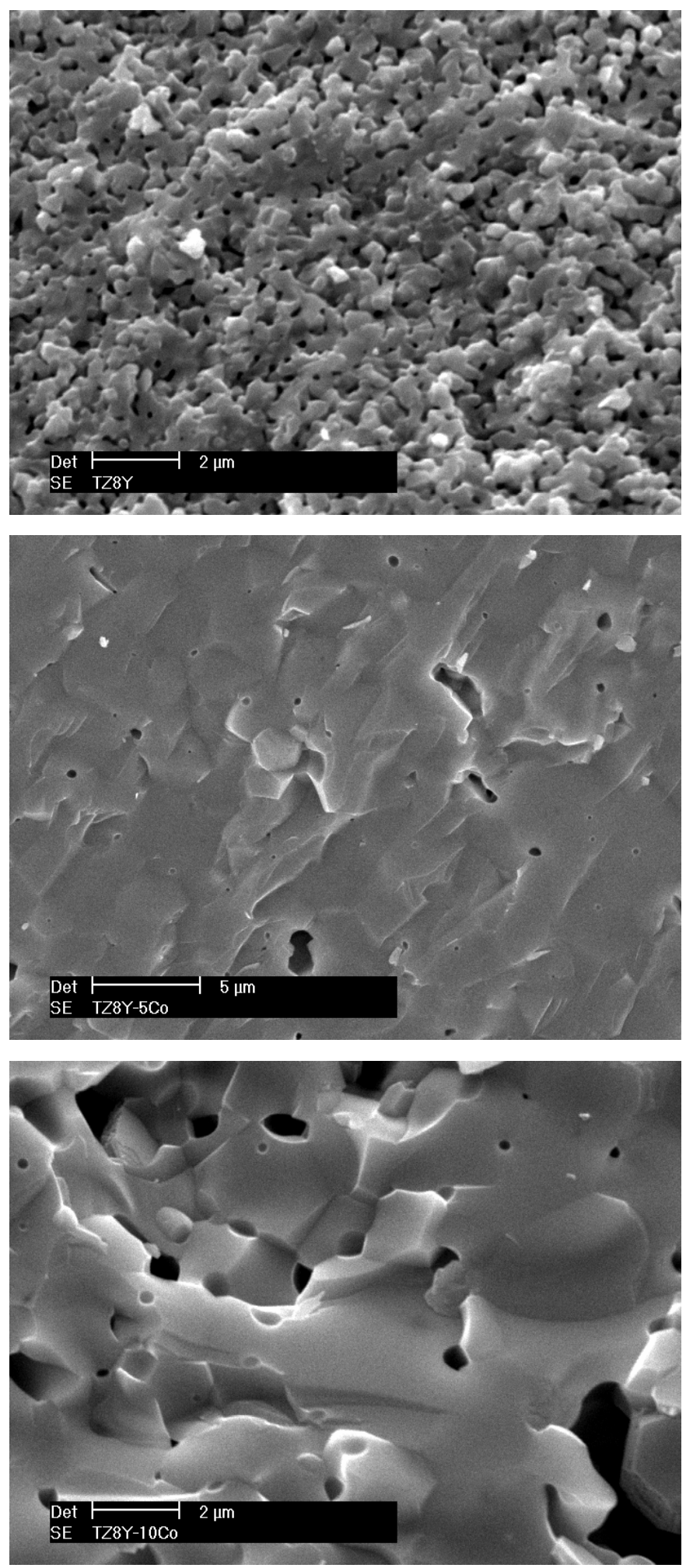

FIGURA 18 - Micrografias obtidas em microscópio eletrônico de varredura de superfícies de fratura das amostras 8YSZ (superior), 8YSZ + 5,0\% (centro) e $8 Y S Z+10,0 \%$ mol Co (inferior), sinterizadas a $1300 \stackrel{\circ}{\circ} / 0,5 \mathrm{~h}$. 
Nestas amostras com o aditivo, figura 18 (centro e inferior), o tipo predominante de fratura é transgranular, assim como na 8YSZ (superior). Observa-se também que o Co promove aumento no tamanho de grãos, embora a quantificação deste efeito não possa ser feita por essas imagens.

$\mathrm{Na}$ figura 19 são mostrados os difratogramas de raios $X$ para as composições $8 Y S Z+x \%$ mol Co com $x=5,0$ (a); 7,5 (b) e 10,0 (c).

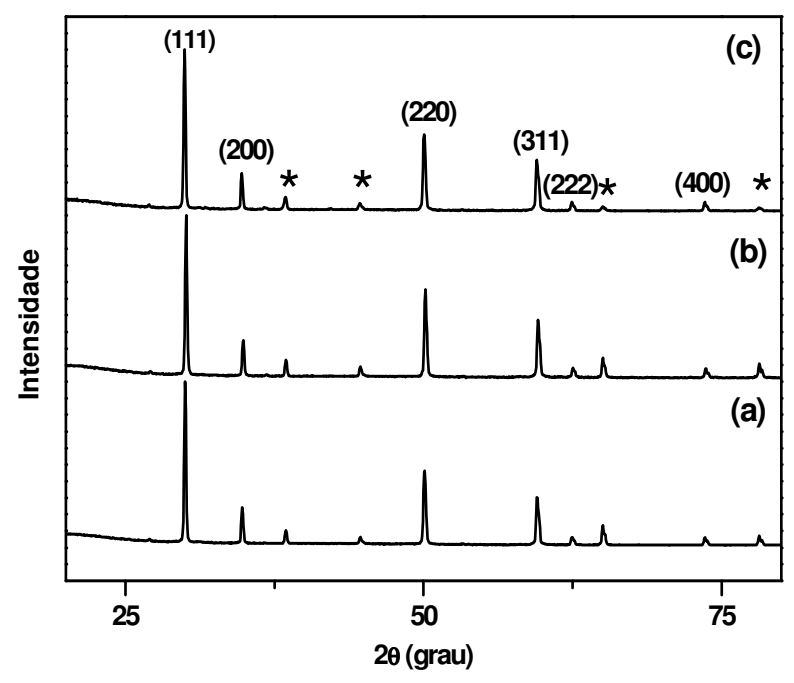

FIGURA 19 - Difratogramas de raios $X$ das amostras sinterizadas a $1200 \stackrel{\circ}{\circ} /$ 0,5 h. (a) $8 Y S Z+5,0 \% \mathrm{~mol} \mathrm{Co}$, (b) $8 Y S Z+7,5 \% \mathrm{~mol} \mathrm{Co} \mathrm{e} \mathrm{(c)} 8 Y S Z+10,0 \%$ em mol de $\mathrm{Co}$; ${ }^{*} \mathrm{Co}_{3} \mathrm{O}_{4}$.

Os difratogramas das diferentes composições têm como características gerais as mesmas reflexões, típicas da zircônia totalmente estabilizada com ítria na fase cúbica (estrutura cúbica de faces centradas, grupo espacial Fm3m, arquivo JCPDF 30-1468). Os picos relacionados com as reflexões mais intensas estão indexados na figura superior (c). Uma característica comum nesses difratogramas é que todos também apresentam os picos do $\mathrm{Co}_{3} \mathrm{O}_{4}$ (estrutura cristalina cúbica, grupo espacial Fd3m, arquivo JCPDF 42-1467), que estão indicados por *.

Estes resultados mostram também que a solubilidade do Co na 8YSZ é inferior a 5,0\% mol para as condições de sinterização utilizadas (1200 ${ }^{\circ} \mathrm{C} / 0,5$ h). 
A análise de fases foi também realizada com o auxílio da espectroscopia Raman. A figura 20 mostra os resultados das amostras $8 Y S Z$ e $8 Y S Z+10,0 \%$ mol Co.

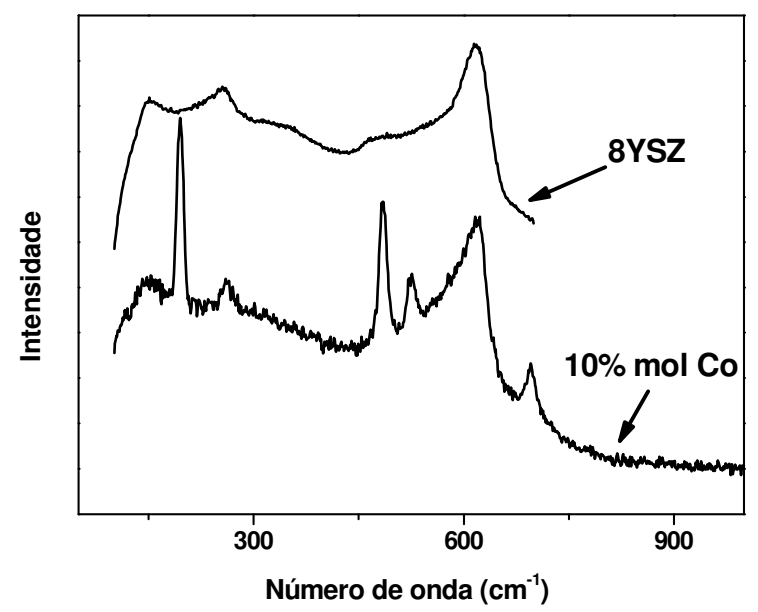

FIGURA 20 - Espectros Raman das amostras 8YSZ sinterizada a $1300{ }^{\circ} \mathrm{C} / 0,5$ h e $8 Y S Z+10,0 \%$ mol Co sinterizada a $1200 \stackrel{\circ}{C} / 0,5$ h

O espectro Raman da amostra 8YSZ já reportado na literatura [55], consiste de um único modo ativo Raman em $\sim 616 \mathrm{~cm}^{-1}$, atribuído ao modo $F_{2 g}$ triplamente degenerado, característico da simetria cúbica de faces centradas. Entretanto, neste caso como em outros trabalhos, observam-se bandas Raman adicionais de baixa intensidade e baixos números de onda, que são freqüentemente associadas com a fase tetragonal como impureza na cerâmica sinterizada, e que não é detectada por difração de raios $X$ [55].

O espectro da amostra $8 Y S Z+10,0 \%$ mol Co mostra que houve um deslocamento da principal banda Raman para $\sim 622 \mathrm{~cm}^{-1}$. Nesse espectro podem também ser observadas bandas adicionais em 196, 485, 523 e 696 $\mathrm{cm}^{-1}$. O CoO apresenta bandas em 484 e $691 \mathrm{~cm}^{-1}$ [56], enquanto que o $\mathrm{Co}_{3} \mathrm{O}_{4}$ apresenta as bandas centradas em 192, 478, 516, 615 e $680 \mathrm{~cm}^{-1}$ [56, 57]. Assim, comparando os resultados obtidos com aqueles já conhecidos, pode-se afirmar que quando o Co é adicionado em teores superiores ao limite de solubilidade na zircônia totalmente estabilizada com ítria, sua forma preferencial após sinterização é $\mathrm{Co}_{3} \mathrm{O}_{4}$. Entretanto pelas proximidades das máximas amplitudes das bandas Raman do $\mathrm{CoO}$ e $\mathrm{Co}_{3} \mathrm{O}_{4}$, não é possível afirmar a inexistência da fase $\mathrm{CoO}$ nestas amostras. 
Para a determinação do tamanho de grão, foram analisadas micrografias das amostras seccionadas transversalmente.

A figura 21 mostra micrografias obtidas em microscópio eletrônico de varredura da superfície polida e atacada termicamente das amostras de 8YSZ contendo 1,0; 5,0 e 10,0\% em mol de Co.
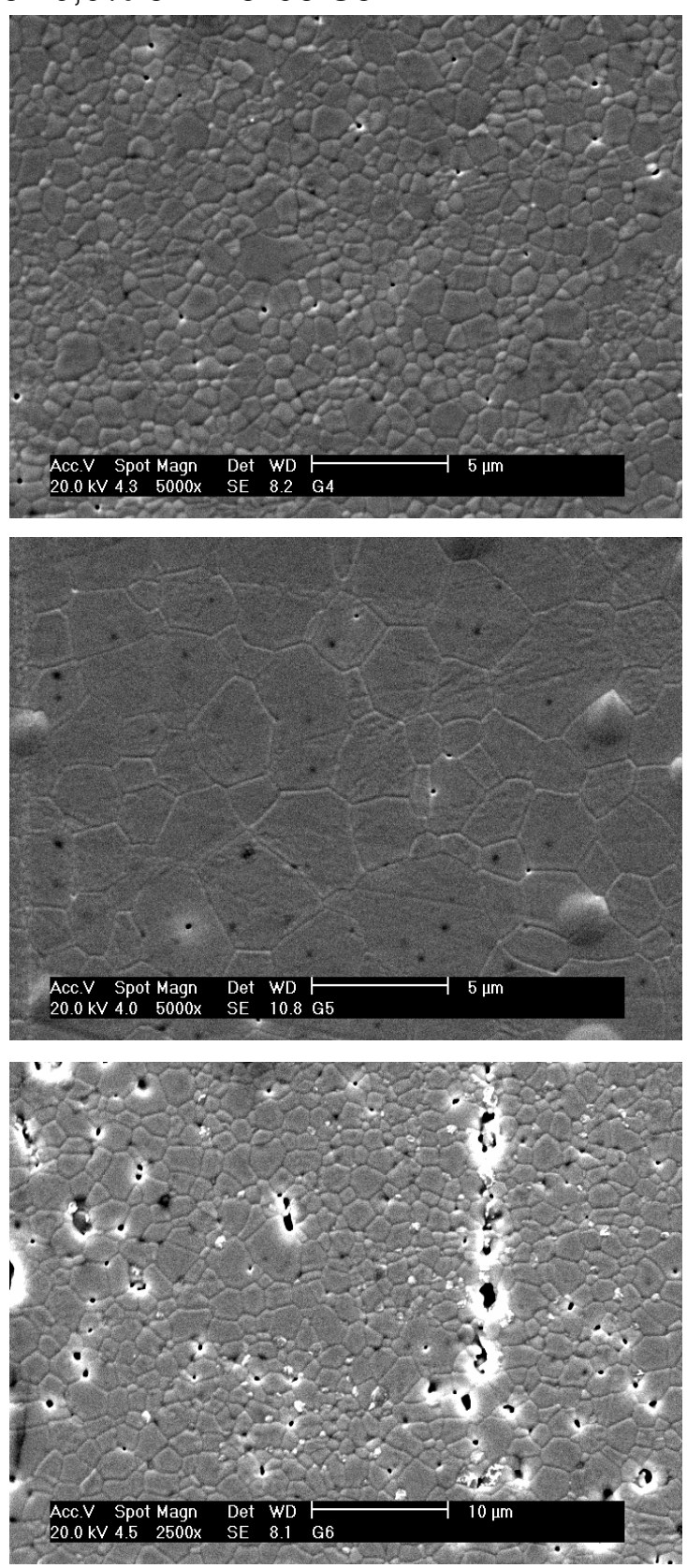

FIGURA 21 - Micrografias obtidas em microscópio eletrônico de varredura de superfícies polidas e atacadas termicamente das amostras $8 Y S Z+1,0 \% \mathrm{~mol}$ de Co (superior), $8 \mathrm{YSZ}+5,0 \% \mathrm{~mol}$ de Co (centro), e $8 \mathrm{YSZ}+10,0 \% \mathrm{~mol}$ de Co (inferior), sinterizadas a $1300^{\circ} \mathrm{C} / 0,5 \mathrm{~h}$. 
Com o aumento do teor de Co, há uma redução da porosidade, como pode ser visto na figura 21 para as amostras com 1,0\% mol Co (superior) e $5,0 \% \mathrm{~mol}$ Co (centro). Para as amostras contendo $1,0 \% \mathrm{~mol}$ Co os poros encontram-se nos contornos de grãos ou nas junções de 3 grãos (poros abertos ou intergranular) e para a amostra de $5,0 \% \mathrm{~mol}$ Co, os poros estão no contorno de grão como também no interior dos grãos (poros fechados ou intragranular). $O$ tamanho dos grãos aumenta consideravelmente também, com o aumento do teor de cobalto. Nestas amostras, figura 21 (superior e centro), os grãos têm uma distribuição de tamanho alargado e formato poligonal.

Entretanto, para a amostra $8 \mathrm{YSZ}+10,0 \%$ mol Co (figura 21 inferior), houve uma diminuição do tamanho do grão, e aumento da porosidade. Este resultado comprova as medidas de densidade em relação ao teor de Co, para amostras sinterizadas a $1300 \stackrel{\circ}{\circ} / 0,5 \mathrm{~h}$, como mostrado na figura 22 .

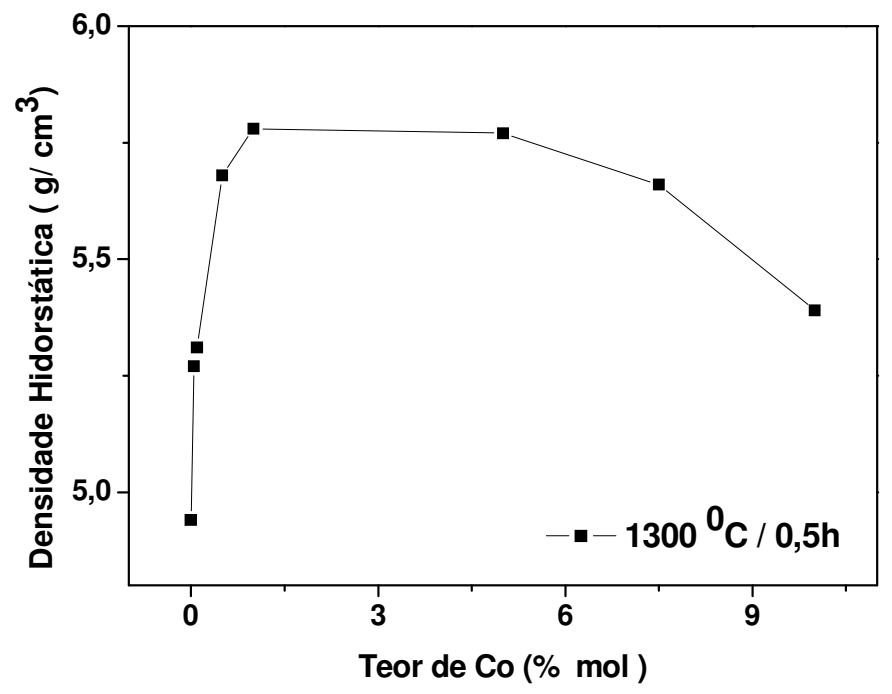

FIGURA 22 - Densidades das amostras sinterizadas a $1300{ }^{\circ} \mathrm{C} / 0,5 \mathrm{~h}$.

A densidade das amostras sinterizadas aumenta até 1,0\% mol de Co, entre 1 e 5,0 \% mol Co, aproximadamente, a densidade permanece constante, diminuindo para teores superiores. Lembrando (tabelas 1 e 3 ) que as densidades da $8 \mathrm{YSZ}$ e $\mathrm{Co}_{3} \mathrm{O}_{4}$ são próximas, a diminuição da densidade para altos teores de Co impõe uma limitação quanto ao teor máximo desse aditivo na 8YSZ.

A tabela 7 mostra valores do tamanho médio de grãos $(\mathrm{G})$, obtido pelo método de Mendelson, para amostras sinterizadas a $1300 \stackrel{\circ}{\circ} / 0,5 \mathrm{~h}$. 
TABELA 7 - Valores de tamanho médio do grão $(G)$, obtido pelo método Mendelson, para amostras sinterizadas a $1300{ }^{\circ} \mathrm{C} / 0,5 \mathrm{~h}$.

\begin{tabular}{cc}
\hline Teor nominal de Cobalto $(\% \mathbf{~ m o l})$ & $\mathbf{G}(\boldsymbol{\mu m})$ \\
\hline $\mathbf{1 , 0}$ & $0,86 \pm 0,19$ \\
$\mathbf{5 , 0}$ & $2,78 \pm 0,30$ \\
$\mathbf{1 0 , 0}$ & $2,76 \pm 0,48$ \\
\hline
\end{tabular}

Os valores mostrados nessa tabela são muito inferiores àqueles obtidos por Hartmanová [30], que utilizou uma matriz 12YSZ, sinterizando o material a $1427 \stackrel{\circ}{\circ}$ / 1 h $(9,5$ a 15,5 $\mu \mathrm{m})$. Este resultado indica uma forte influência da temperatura de sinterização no crescimento dos grãos da 8YSZ com adição de Co.

A figura 23 mostra micrografias obtidas em microscópio eletrônico de varredura de superfícies polidas e atacadas termicamente das amostras 8YSZ (superior), $8 Y S Z+0,5 \% \mathrm{~mol}$ Co (centro), $8 Y S Z+1,0 \% \mathrm{~mol}$ Co (inferior), sinterizadas a $1400 \stackrel{\circ}{\circ} / 0,5 \mathrm{~h}$. 

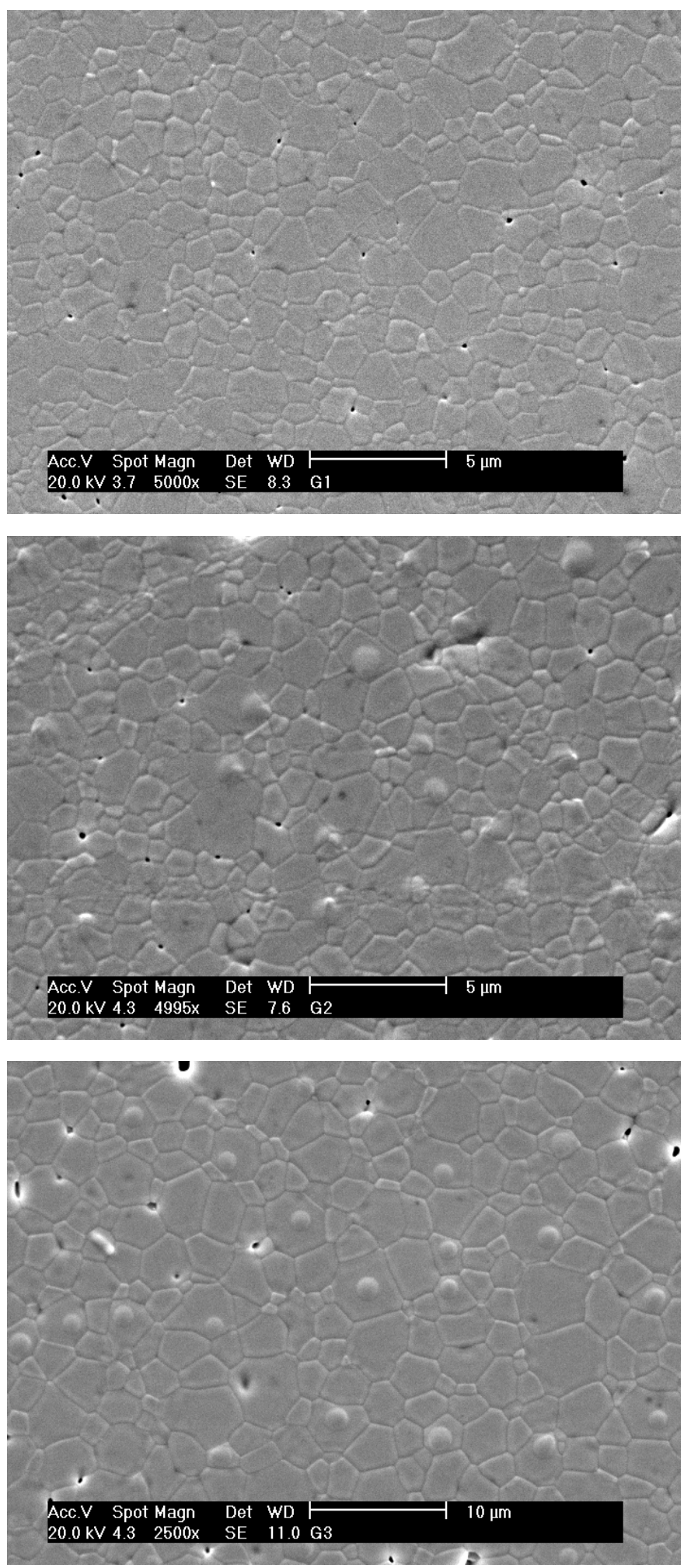

FIGURA 23 - Micrografias obtidas em microscópio eletrônico de varredura de superfícies polidas e atacadas termicamente das amostras 8YSZ (superior), $8 Y S Z+0,5 \% \mathrm{~mol}$ Co (centro), $8 Y S Z+1,0 \% \mathrm{~mol}$ Co (inferior), sinterizadas a $1400 \stackrel{\circ}{C} / 0,5 \mathrm{~h}$. 
Verifica-se novamente que com o aumento do teor de Co, há aumento no tamanho dos grãos, figura 23 e tabela 8.

A tabela 8 mostra os valores de tamanho médio do grão $(G)$, obtidos pelo método Mendelson, para amostras sinterizadas a $1400{ }^{\circ} \mathrm{C} / 0,5 \mathrm{~h}$.

Comparando amostras com mesmo teor de Co e temperaturas de sinterização diferentes, $1300{ }^{\circ} \mathrm{C} / 0,5 \mathrm{~h}$ (figura 21 superior) e $1400{ }^{\circ} \mathrm{C} / 0,5 \mathrm{~h}$ (figura 23, inferior) verifica-se aumento substancial no tamanho dos grãos com aumento na temperatura de sinterização.

TABELA 8 - Valores de tamanho médio do grão $(G)$, obtido pelo método Mendelson, para amostras sinterizadas a $1400 \stackrel{\circ}{\circ} \mathrm{C} / 0,5 \mathrm{~h}$.

\begin{tabular}{cc}
\hline Teor nominal de Cobalto $(\% \mathrm{~mol})$ & $\mathbf{G}(\boldsymbol{\mu m})$ \\
\hline $\mathbf{0}$ & $1,40 \pm 0,14$ \\
$\mathbf{0 , 5}$ & $1,54 \pm 0,06$ \\
$\mathbf{1 , 0}$ & $2,98 \pm 0,16$ \\
\hline
\end{tabular}

Para a amostra contendo $1,0 \% \mathrm{~mol} \mathrm{Co}$, com o aumento de $100{ }^{\circ} \mathrm{C}$ na temperatura de sinterização, aumentou o tamanho do grão por um fator de $\sim 3$.

A figura 24 mostra os valores de densidade hidrostática para amostras sinterizadas a diferentes temperaturas de patamar e tempos de patamar. É importante observar que para os mesmos teores de Co, há uma variação de densidade das amostras para diferentes temperaturas e tempos de sinterização.

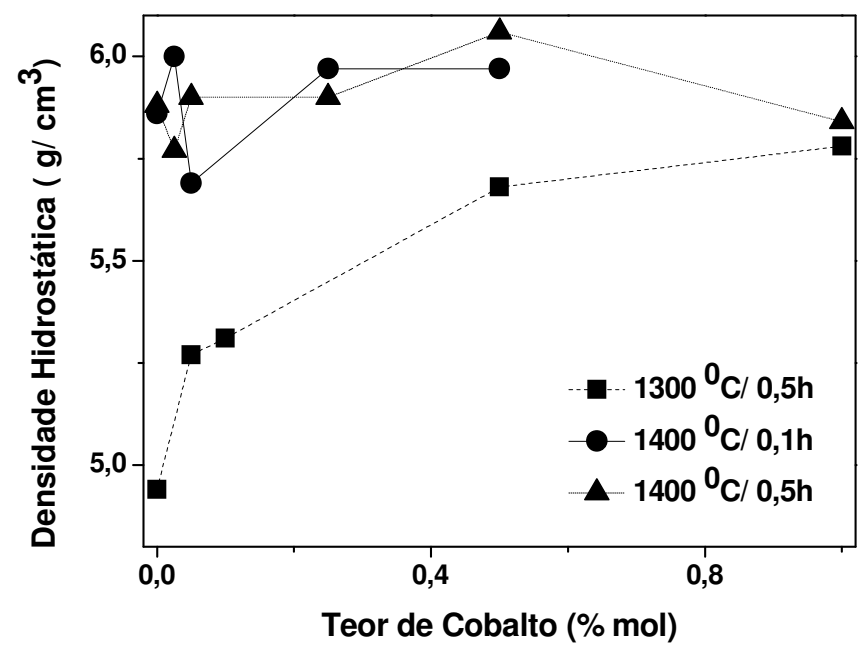

FIGURA 24 - Densidade hidrostática das amostras sinterizadas em diversas temperaturas e tempos de patamar em função do teor de Co. 
Independentemente do tempo de sinterização, as amostras sinterizadas a $1400 \stackrel{\circ}{\circ}$ atingiram altos valores de densidade $\left(>5,7 \mathrm{~g} / \mathrm{cm}^{3}\right)$. Além disso, pequenos teores de cobalto são suficientes para maximizar a densidade na temperatura de $1400^{\circ} \mathrm{C}$. Para temperatura de patamar de $1300{ }^{\circ} \mathrm{C}$, o comportamento é diferente, a densidade aumenta gradativamente até $1,0 \% \mathrm{~mol}$ Co.

Esses resultados de microscopia e densidade mostram que, apesar do Co promover a densificação da 8YSZ, é necessário ainda o emprego de temperaturas da ordem de $1400 \stackrel{\circ}{\circ}$ para a sinterização. O cobalto acelera o crescimento dos grãos e este efeito é fortemente influenciado pela temperatura de sinterização.

Para finalizar, são apresentados os resultados de medidas da condutividade elétrica para diversas amostras preparadas.

Inicialmente serão apresentados os resultados para amostras sinterizadas a $1300 \stackrel{\circ}{\circ} / 0,5 \mathrm{~h}$, em seguida, para as amostras sinterizadas a $1400 \stackrel{\circ}{\circ} / 0,1 \mathrm{~h}$ e por fim para as amostras sinterizadas a $1400 \stackrel{\circ}{\circ} \mathrm{C} / 0,5 \mathrm{~h}$.

A figura 25 mostra diagramas de impedância obtidos para as composições: $8 Y S Z$ e $8 Y S Z+x \%$ mol Co com $x=0,05$ e 0,5, sinterizadas a $1300 \stackrel{\circ}{\circ} / 0,5 \mathrm{~h}$. A temperatura de medida está em cada diagrama.

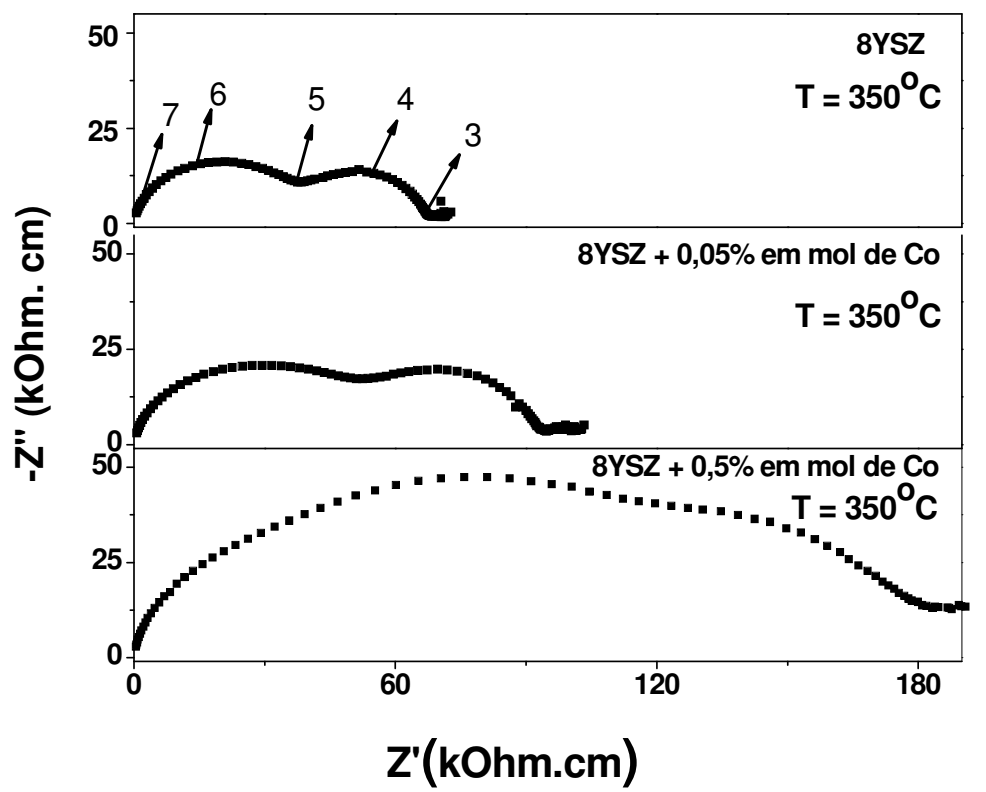

FIGURA 25 - Diagramas de impedância das amostras $8 Y S Z$ e $8 Y S Z+x \% \mathrm{~mol}$ Co, onde $x=0,05$ e 0,5 . Amostras sinterizadas a $1300 \stackrel{\circ}{C} / 0,5 \mathrm{~h}$. 
Os diagramas das amostras com $\mathrm{x}=0$ e 0,05 apresentam dois semicírculos relacionados com o processo de condução através dos grãos (alta freqüência) e dos contornos de grão (baixa freqüência). A amostra com $x=0,5$ apresenta um terceiro semicírculo intermediário entre os outros do eletrólito. Este novo semicírculo está provavelmente relacionado com uma (micro) trinca na amostra.

A análise dos resultados de medidas da condutividade elétrica em diversas temperaturas, para as várias amostras, permitiu construir o gráfico de Arrhenius da condutividade elétrica total (grão + contorno de grão), como mostrado na figura 26.

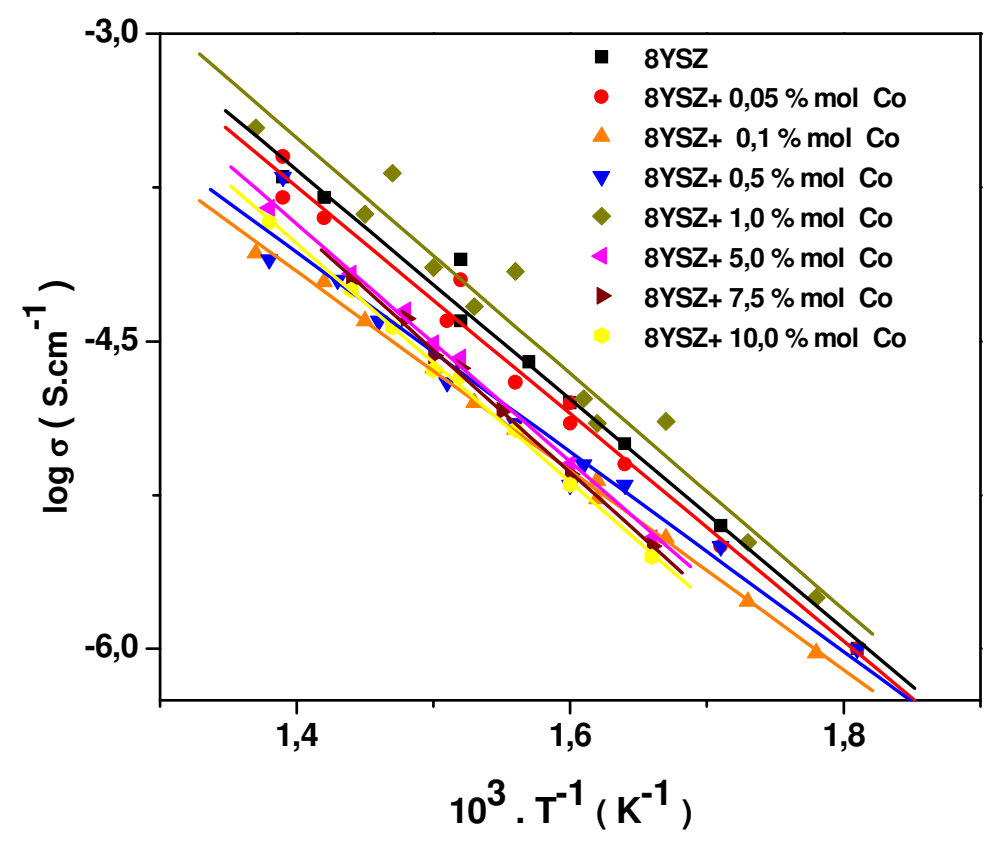

FIGURA 26 - Gráficos de Arrhenius da condutividade elétrica total das amostras $8 Y S Z$ e $8 Y S Z+x \%$ mol Co, onde $x=0,05 ; 0,1 ; 0,5 ; 1,0 ; 5,0 ; 7,5$ e 10,0. Amostras sinterizadas a $1300 \stackrel{\circ}{\mathrm{C}} / 0,5 \mathrm{~h}$.

A condutividade elétrica total das amostras sinterizadas a $1300 \stackrel{\circ}{\circ}$ contendo Co é inferior à da $8 Y S Z$ exceto para a composição contendo $1 \% \mathrm{~mol}$ Co. O efeito do Co na zircônia estabilizada com ítria é bastante controverso. Hartmanová e colaboradores [30] mostraram que para adições de 0,1\% em massa de $\mathrm{Co}_{2} \mathrm{O}_{3}$ a condutividade elétrica do grão na zircônia contendo $12 \%$ mol ítria, aumenta e, para teores superiores, diminui. Stochniol e colaboradores 
[31], por outro lado, determinaram que a $8 \mathrm{YSZ}$ contendo $5,0 \%$ mol Co possui condutividade elétrica mais elevada que a 8YSZ, e sugeriu que esse efeito pode estar relacionado com o aumento na condução eletrônica. Em trabalho mais recente, Lewis e colaboradores [32], assumindo que o processo de condução é puramente iônico, mostraram que a condutividade elétrica da 8YSZ diminui qualquer que seja o teor de $\mathrm{Co}$, mas que para teores até $1,0 \%$ at., a diminuição na condutividade é desprezível.

Para estudar o efeito do Co nos grãos e nos contornos de grão, amostras com diferentes teores de Co foram sinterizadas a $1400 \stackrel{\circ}{\circ} / 0,1$ e 0,5 h.

A figura 27 mostra diagramas de impedância das amostras 8YSZ e $8 Y S Z+0,05 \%$ e $0,5 \%$ mol Co sinterizadas a $1400 \stackrel{\circ}{C} / 0,1 \mathrm{~h}$.

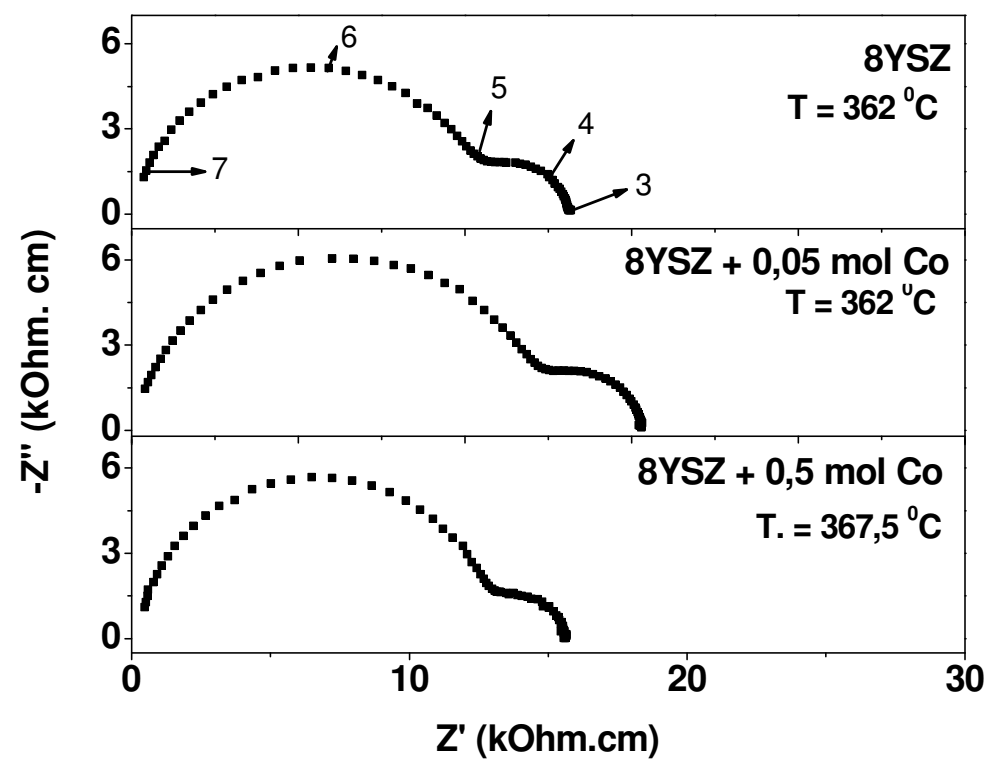

FIGURA 27 - Diagrama de impedância das amostras 8YSZ e 8YSZ + $\mathrm{x} \% \mathrm{~mol}$ Co, onde $x=0,05$ e 0,5 . Amostras sinterizadas a $1400{ }^{\circ} \mathrm{C} / 0,1 \mathrm{~h}$.

Os diagramas são similares àqueles das amostras sinterizadas a 1300 ${ }^{\circ} \mathrm{C} /$ 0,5 h. Entretanto, neste caso, não se observa uma variação significativa da resistividade (condutividade) com o teor de Co.

Isto pode ser visto mais claramente nos gráficos de Arrhenius mostrados nas figuras 28 e 29, para as condutividades intragranular e intergranular, respectivamente. 


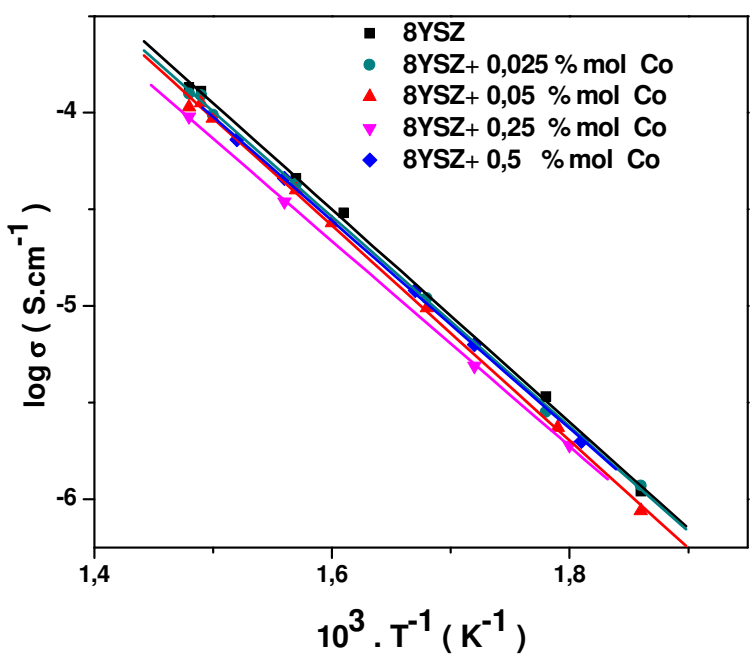

FIGURA 28 - Gráficos de Arrhenius da condutividade elétrica dos grãos das amostras 8YSZ e 8YSZ+ $\mathrm{x} \% \mathrm{~mol}$ Co, onde $\mathrm{x}=0,025 ; 0,05 ; 0,25$ e 0,5 . Amostras sinterizadas a $1400 \stackrel{\circ}{\circ} / 0,1 \mathrm{~h}$.

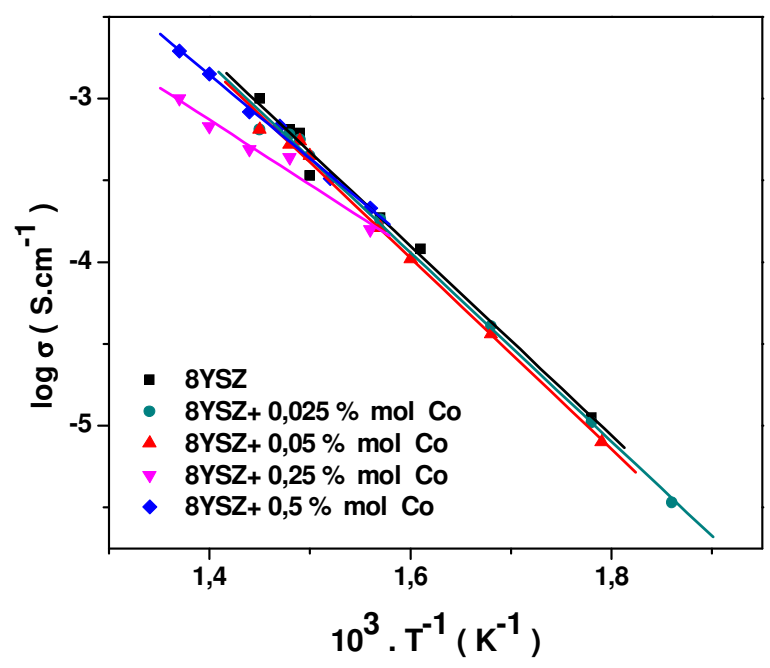

FIGURA 29 - Gráficos de Arrhenius da condutividade elétrica dos contornos de grão das amostras $8 Y S Z$ e $8 Y S Z+x \%$ mol Co, onde $x=0,025 ; 0,05 ; 0,25$ e 0,5 . Amostras sinterizadas a $1400 \stackrel{\circ}{\circ} / 0,1 \mathrm{~h}$.

Pode ser visto nas figuras 28 e 29 , que as amostras contendo Co, possuem um comportamento similar ao da amostras $8 \mathrm{YSZ}$ sem aditivo.

A figura 30 mostra diagramas de impedância das amostras 8YSZ e $8 Y S Z+0,05 \%$ e $0,5 \%$ mol Co sinterizadas a $1400 \stackrel{\circ}{\circ} / 0,5 \mathrm{~h}$. 


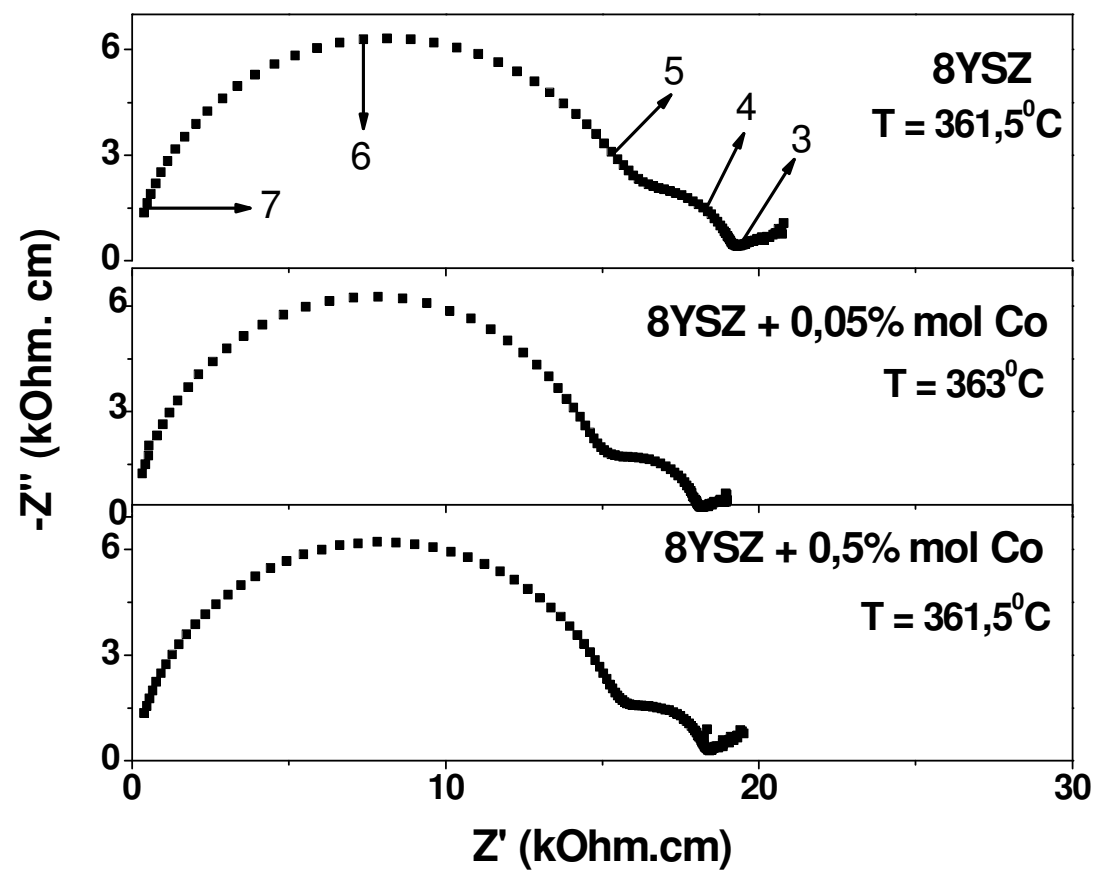

FIGURA 30 - Diagramas de impedância de amostras 8YSZ e 8YSZ + x\% mol Co $\operatorname{com} x=0,05$ e 0,5 sinterizadas a $1400^{\circ} \mathrm{C} / 0,5 \mathrm{~h}$.

Os diagramas apresentam dois semicírculos na faixa de freqüência utilizada, da mesma forma que nos casos anteriores, que estão relacionados com o processo de condução através dos grãos (alta freqüência) e dos contornos de grão (baixa freqüência). Pode-se então concluir que, o teor do aditivo é relativamente pequeno para produzir alguma alteração na forma dos diagramas de impedância. A análise das medidas na faixa de temperaturas entre 250 e $450 \stackrel{\circ}{\mathrm{C}}$ permitiu construir os gráficos de Arrhenius da condutividade intragranular (figura 31) e intergranular (figura 32). 


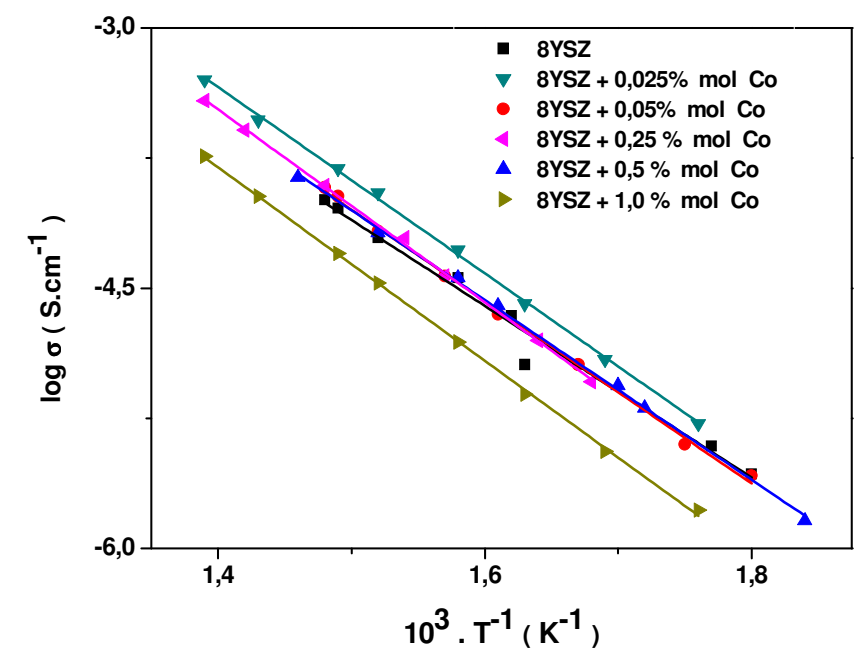

FIGURA 31 - Gráficos de Arrhenius da condutividade elétrica dos grãos das amostras 8YSZ e 8YSZ+ $\mathrm{x} \% \mathrm{~mol} \mathrm{Co}$, onde $\mathrm{x}=0,025 ; 0,05 ; 0,25 ; 0,5$ e 1,0 . Amostras sinterizadas a $1400^{\circ} \mathrm{C} / 0,5 \mathrm{~h}$.

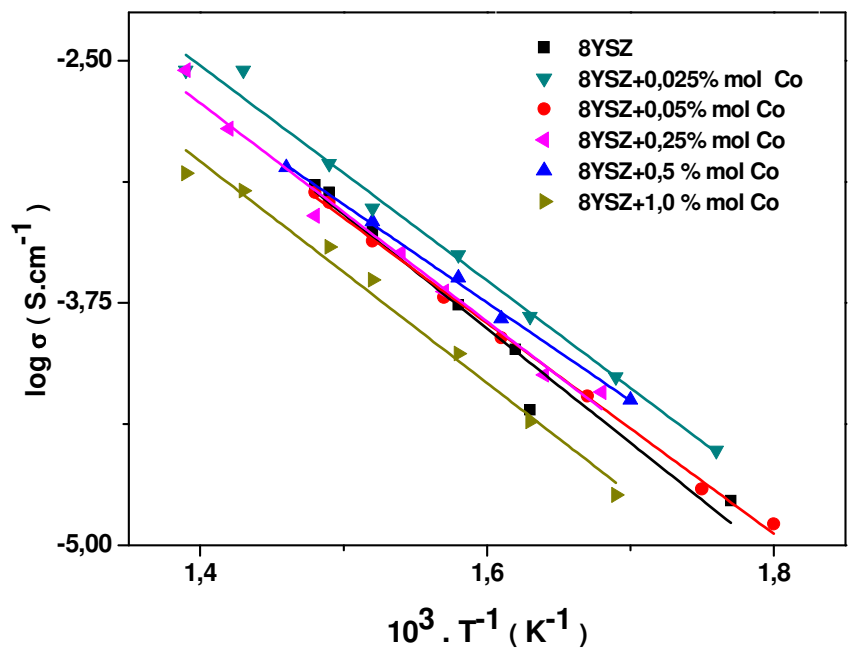

FIGURA 32 - Gráficos de Arrhenius da condutividade elétrica dos contornos de grão das amostras $8 Y S Z$ e $8 Y S Z+x \%$ mol Co, onde $x=0,025 ; 0,05 ; 0,25 ; 0,5$ e 1,0 . Amostras sinterizadas a $1400 \stackrel{\circ}{\circ} / 0,5 \mathrm{~h}$.

A condutividade intragranular das amostras contendo Co é da mesma ordem de grandeza que aquela da 8YSZ sem aditivo, com exceção da amostra com $1,0 \%$ mol Co, que apresenta uma condutividade de menor que as demais. 
Há também um pequeno aumento da condutividade intragranular da amostra contendo $0,025 \% \mathrm{~mol}$ Co.

Comportamento similar foi observado para a condutividade dos contornos de grão. Este resultado indica que o processo de condução deve continuar sendo predominantemente iônico para pequenos teores de Co. Assim, um pequeno aumento da condutividade para a amostra contendo 0,025\% mol Co, pode estar relacionado com aumento na concentração vacâncias de oxigênio devido à incorporação do aditivo na estrutura cristalina, que consiste de uma mistura de $\mathrm{Co}^{3+}$ e $\mathrm{Co}^{4+}$, provavelmente também $\mathrm{Co}^{2+}$. Portanto, parte do aditivo incorporado pode aumentar a concentração de vacâncias de oxigênio disponíveis para a difusão.

Hartmanová [30] observou que a condutividade da 12YSZ aumenta até $0,1 \%$ massa de $\mathrm{CO}_{2} \mathrm{O}_{3}$, que seria equivalente a $0,03 \%$ mol Co na $8 Y S Z$.

Lewis [32] também não observou variação na condutividade total nas amostras $8 Y S Z$ até $1,0 \%$ mol Co, sinterizadas a $1250{ }^{\circ} \mathrm{C} / 2 \mathrm{~h}, 1290{ }^{\circ} \mathrm{C} / 2 \mathrm{~h}$ e $1330 \stackrel{\circ}{\mathrm{C}} / 2 \mathrm{~h}$.

Dessa forma pode-se afirmar que os resultados obtidos neste trabalho concordam com aqueles de Hartmanová [30] quanto ao aumento pequeno na condutividade em teores de Co de 0,025\%, e que também estão de acordo com os de Lewis [32] obtendo-se diminuição da condutividade para altos teores de Co.

Resultados similares também foram observados quando o óxido de lantânio foi adicionado à matriz 8YSZ [7], sendo que a relação entre o teor de $\mathrm{La}_{2} \mathrm{O}_{3}$ e a condutividade não foi linear. A explicação dos autores para esse efeito foi a perda de $\mathrm{La}_{2} \mathrm{O}_{3}$ por evaporação e conseqüente aumento da porosidade. Os resultados de microestrutura obtidos neste trabalho sugerem que essa explicação talvez possa ser aplicada ao Co na 8YSZ.

Comparando os resultados obtidos neste trabalho com os da literatura pode-se dizer que a condutividade elétrica da 8YSZ contendo Co não depende apenas do teor do aditivo, mas também das condições de processamento e de sinterização.

As tabelas 9, 10 e 11 mostram valores da energia de ativação para o processo de condução para as amostras estudadas neste trabalho. $O$ valor do erro nesses cálculos está em torno de $\pm 0,05 \mathrm{eV}$. 
Na tabela 9, são mostrados os valores de energia de ativação calculados paras as amostras sinterizadas a $1300{ }^{\circ} \mathrm{C} / 0,5 \mathrm{~h}$. A energia de ativação do processo de condução aumenta com o aumento do teor de cobalto.

TABELA 9 - Valores de energia de ativação do processo de condução dos grãos, contornos de grão e total, para amostras sinterizadas a $1300{ }^{\circ} \mathrm{C} / 0,5 \mathrm{~h}$.

\begin{tabular}{c|ccc}
\hline $\begin{array}{c}\text { Teor de Cobalto } \\
(\% \text { mol })\end{array}$ & \multicolumn{3}{|c}{ Energia de Ativação (eV $\pm \mathbf{0 , 0 5} \mathbf{~ V V})$} \\
\cline { 2 - 4 } & Grão & Contorno de grão & Total \\
\hline $\mathbf{0}$ & - & - & 1,09 \\
$\mathbf{0 , 0 5}$ & - & - & 1,09 \\
$\mathbf{0 , 1}$ & - & - & 0,98 \\
$\mathbf{0 , 5}$ & - & - & 0,96 \\
$\mathbf{1 , 0}$ & 1,13 & 1,17 & 1,14 \\
$\mathbf{5 , 0}$ & 1,19 & 1,16 & 1,14 \\
$\mathbf{7 , 5}$ & 1,19 & 1,17 & 1,18 \\
$\mathbf{1 0 , 0}$ & 1,21 & 1,12 & 1,15 \\
\hline
\end{tabular}

Para as amostras sinterizadas a $1400{ }^{\circ} \mathrm{C} / 0,1 \mathrm{~h}$, tabela 10 , bem como para as demais amostras analisadas, os valores da energia de ativação estão em torno de $1 \mathrm{eV}$, que é característico dos condutores de íons oxigênio [12].

TABELA 10 - Valores de energia de ativação do processo de condução dos grãos, contornos de grão e total, para amostras sinterizadas a $1400 \stackrel{\circ}{\circ} / 0,1 \mathrm{~h}$.

\begin{tabular}{c|ccc}
\hline \multirow{2}{*}{$\begin{array}{c}\text { Teor de Cobalto } \\
(\% \text { mol) }\end{array}$} & \multicolumn{3}{|c}{ Energia de Ativação $(\mathbf{e V} \pm \mathbf{0 , 0 5} \mathrm{eV})$} \\
\cline { 2 - 4 } & Grão & Contorno de grão & Total \\
\hline $\mathbf{0}$ & 1,09 & 1,14 & 1,08 \\
$\mathbf{0 , 0 2 5}$ & 1,07 & 1,18 & 1,10 \\
$\mathbf{0 , 0 5}$ & 1,10 & 1,17 & 1,12 \\
$\mathbf{0 , 2 5}$ & 1,05 & - & 1,02 \\
$\mathbf{0 , 5}$ & 1,07 & 1,01 & 1,09 \\
\hline
\end{tabular}


Finalmente, para as amostras sinterizadas a $1400{ }^{\circ} \mathrm{C} / 0,5 \mathrm{~h}$, tabela 11 , a energia de ativação da condução intragranular aumenta com o aumento do teor de Co, mas para a condutividade dos contornos de grão este comportamento é inverso.

TABELA 11 - Valores de energia de ativação do processo de condução dos grãos, contornos de grão e total, para amostras sinterizadas a $1400^{\circ} \mathrm{C} / 0,5 \mathrm{~h}$.

\begin{tabular}{c|ccc}
\hline \multirow{2}{*}{$\begin{array}{c}\text { Teor de Cobalto } \\
\text { (\% mol) }\end{array}$} & \multicolumn{3}{|c}{ Energia de Ativação (eV $\pm \mathbf{0 , 0 5}$ eV) } \\
\cline { 2 - 4 } & Grão & Contorno de grão & Total \\
\hline $\mathbf{0}$ & 0,98 & 1,17 & 1,05 \\
\hline $\mathbf{0 , 0 2 5}$ & 1,07 & 1,11 & 1,05 \\
$\mathbf{0 , 0 5}$ & 1,04 & 1,07 & - \\
$\mathbf{0 , 2 5}$ & 1,09 & 1,11 & 1,10 \\
$\mathbf{0 , 5}$ & 1,20 & 1,00 & 1,02 \\
$\mathbf{1 , 0}$ & 1,10 & 1,13 & 1,09 \\
\hline
\end{tabular}

Os resultados principais deste trabalho mostram que o Co é pouco efetivo para a densificação da 8YSZ em baixos teores (<1,0\% mol Co), quando também promove pequeno aumento da condutividade elétrica da cerâmica. Entretanto, a melhoria na densificação não é suficiente para reduzir a temperatura de sinterização de forma considerável.

Dependendo das condições de sinterização e do teor de Co, não se observa alteração significativa na condutividade elétrica. 


\section{5 - CONCLUSÕES}

- O Co como aditivo promove densificação limitada na 8YSZ para teores até $1,0 \% \mathrm{~mol}$;

- As amostras sinterizadas a $1400{ }^{\circ} \mathrm{C}$ atingiram altos valores de densidade e pequenos teores de cobalto são suficientes para maximizar a densidade nesta temperatura;

- A temperatura de sinterização na 8YSZ com aditivo, continua sendo superior a $1400^{\circ} \mathrm{C}$;

- A forma predominante como o aditivo é encontrado após a sinterização e em teores acima do limite de solubilidade é $\mathrm{Co}_{3} \mathrm{O}_{4}$;

- O tamanho dos grãos aumenta com o teor de Co e é fortemente dependente da temperatura de sinterização.

- A condutividade elétrica depende das condições de sinterização, e

- A condutividade elétrica da 8YSZ tem pequeno aumento para teores de $0,025 \% \mathrm{~mol}$ Co e diminui para teores igual ou superiores a $1,0 \% \mathrm{~mol}$ Co. 


\section{6 - REFERÊNCIAS BIBLIOGRÁFICAS}

[1] Wachtman, J. B.; MacLaren M. G.; "News Ceramics", trabalho não publicado.

[2] Varela, J. A.; Cerâmica de Alta Tecnologia no Brasil; Brasília; MCT; 1988.

[3] Subbarao, E. C.; Advances In Ceramics; vol. 3; Science and Technology of Zirconia; eds.: A. H. Heuer, L. W. Hobbs; The American Ceramic Society; Columbus, Ohio (1981), pp.1.

[4] McColm, I. J.; Ceramic Science for Materials Technologists; ed. Champman and Hall; New York; (1983); pp.235.

[5] Florio, D.Z. de; Muccillo, R.; Materials Research Bulletin, 39 (2004) 1539.

[6] Verkerk, M. J.; Winnubst, A. J. A.; Burggraaf, A. J.; Journal of Materials Science, 17 (1982) 3113.

[7] Oh, Y. -J.; Jing, H. -J.; Lee, H. S.; in Interfacial Structure, Properties and Design, MRS Symposium Proceedings, v. 122, ed. M. H. Yoo, W. A. T. Clark e C. L. Briant, 1988, Materials Research Society, USA, pp. 497.

[8] Garvie, R.C., High Temperature Oxides, Part II; ed. Alper A. M.; Academic Press; p. 117, 1970.

[9] Stevens, R.; Zirconia and Zirconia Ceramics, Magnesium Elektron Publication, $2^{\text {nd }}$ ed., London, 1986.

[10] Lee, W.E.; Rainforth, W.M.; Ceramic Microstructure - Property Control by Processing; London, U.K.: Chapman \& Hall; $1994 ;$ p.317.

[11] Green, D. J.; Hannink, R.H.J.; Swain, M.V.; Transformation Toughening of Ceramics; Boca Raton, Fla: CRC; 1989.

[12] Solid Electrolytes; ed. P. Hagenmuller, W. Van Gool; Academic Press; New York; 1978.

[13] El- Shobaky, G. A.; Ahmad, A. S.; Al-Noaimi, A. N.; El- Shobaky, H.G.; Journal of Thermal Analysis and Calorimetry; 46 (1996) 1801.

[14] Duval, C.; Duval, R.; Analytica Chimica Acta; 5 (1951) 84.

[15] El- Shobaky, A.; Hewaidy, I. F.; Ghoneim, N. M.; Thermochimica Acta; 53 (1982) 105.

[16] Lange, N. A.; Handbook of Chemistry, ed. Mc Graw-Hill, New York, 1961. 
[17] Agrawal, R. C.; Gupta, R. K.; Journal of Materials Science 34 (1999) 1131.

[18] Kumar, B.; Scanlon, L. G.; Journal of Power Sources, 52 (1994) 261.

[19] Mikrajuddin, A.; Shi, G.; Okuyama, K.; Journal of the Electrochemical Society 147 (2000) 3157.

[20] Knauth, P.; Journal of Electroceramics 5 (2000) 111.

[21] Cosentino, I. C.; Muccillo, E. N. S.; Muccillo, R.; Sensors \& Actuators B96 (2003) 677.

[22] Jones, R. L.; Mess, D.; Surface and Coating Technology 86-87 (1996) 94.

[23] Beatrice, P.; Pliangos, C.; Worrel, W. L.; Vayenas, C. G.; Solid State Ionics, 136 (2000) 833.

[24] Radford, K. C.; Bratton, R. J.; Journal of Materials Science 14 (1979) 66.

[25] Bowen, C.; Ramesh, S.; Gill, C.; Lawson, S.; Journal of Materials Science 33 (1998) 5103.

[26] Chen, S.-Y.; Lu, H.-Y.; Journal of Materials Science 30 (1995) 1321.

[27] Lee, J. H.; Yoshimura, M.; Solid State Ionics 139 (2001) 197.

[28] Ziesche, S.; Trofimenko, N.; Kuznecov, M.; Priedel, W.; Proccedings $26^{\text {th }}$

Riso International Symposium on Materials Science: Solid State Electrochemistry; ed. S. Linderoth, A. Smith, N. Bonanos, A. Hagen, L. Mikkelsen, K. Kammer, D. Lybye, P. V. Hendriksen, F. W. Poulsen, M. Mogensen, W. G. Wang, Riso, Denmark, 2005, pp. 375.

[29] Hyatt, E. P.; Christensen, C. J.; Cutler, I.B.; American Ceramic Society Bulletin 36 (1957) 307.

[30] Hartmanová, M.; Hanic, F.; Tunega, D.; Putyera, K.; Chemistry Papers, 52 (1998) 12.

[31] Stochniol, G.; Naoumidis, A.; Nickel, H.; Wippermann, K.; Ruchewitz, U. Characterization of $\mathrm{Ca}$-, $\mathrm{Mn}$ - and Co- containing $\mathrm{Y}_{2} \mathrm{O}_{3}$-stabilized zirconia. In: $23^{\text {rd }}$ International Conference on Microelectronics and $31^{\text {st }}$ Symposium on Devices and Materials; Proceedings, ed. Midem - Soc. Microeletron. Electron. Components \& Mater., p. 245-250, 1995.

[32] Lewis, G. S.; Atkinson, A., Steele, B. C. H.; Journal of Materials Science Letters 20 (2001) 1155.

[33] Silva, A. G. P.; Alves Junior, C.; Cerâmica 44 (1998) 171.

[34] Gomes, U. U.; Tecnologia dos pós: Fundamentos e Aplicações, Universitária UFRN (1995). 
[35] Courtney; T. H.; Metallalurgical Transactions 15 (1984) 180.

[36] Kingery, W. D.; Introductions to Ceramics; ed. John Wiley \& Sons; New York; 1960.

[37] German, R. M.; Liquid Phase Sintering; ed. Plenum Press; New York; 1985.

[38] Cienfuegos, F.; Vaitsman, D.; Análise Instrumental. Rio de Janeiro: Interciência, 2000; p. 523-532.

[39] Vogel, A. I.; Análise Química Quantitativa. 6ª ed. Rio de Janeiro: LTC; 2002; p. 265-271.

[40] Engineered Materials Handbook, vol. 2 - Ceramics; ed. J. Harold Johnson, Robert T. Kiespura, Dorene A. Humphries, 1987 - (582-583)

[41] West, A. R.; Solid State Chemistry and its Applications; John Wiley \& sons; New York; 1984.

[42] Kestenbach, H.J.; Botta Filho, W. J.; Microscopia Eletrônica: Transmissão e Varredura; Associação Brasileira de Metais; São Paulo; 1989.

[43] Padilha, A. F.; Ambrozio Fo; F.; Técnicas de Análise Microestrutural; ed. Hemus 1985.

[44] Goldstein, J. I.; Scanning Electron Microscopy and X-Ray Microanalysis; Plenum Press; New York; 1984.

[45] Speyer F., R.; Thermal Analysis of Materials; ed. Marcel Dekker Inc; New York; 1993.

[46] Sala, O.; Fundamentos da Espectroscopia Raman e no Infravermelho; ed. UNESP; São Paulo; 1995.

[47] Bauerle, J. E.; J. Phys. Chem. Solids 30 (1969) 2657.

[48] Mcdonald, J. R.; Impedance Spectroscopy - Emphasing Solid Materials and Systems; Willey Interscience; New York; 1987.

[49] Kilner, J.A.; Steele, B.C.H; Nonstoichometric Oxides; ed. O.T. Sorensen; Academic Press; New York; 1981.

[50] Kofstad, P. (editor); Nonstoichiometry; Diffusion and Electrical Conductivity in Binary Oxides; Wiley Interscience; New York; 1972.

[51] Kvist, A.; in Physics of Electrolytes; vol. 1; ed. J. Hladik; academic Press; London; 1972.

[52] Mendelson, M. I.; Journal of the American Ceramic Society 52(1969) 443. 
[54] Kleitz, M.; Kennedy, J. H.; in: Fast lon Transport in Solids, Electrodes and Electrolytes; ed. P. Vashishta, J. N. Mundy, G. K. Shenoy; North-Holland, Amsterdam; 1979; p. 185.

[54] Segal, D.; Journal of Materials Chemistry 7 (1997) 1297.

[55] López, E. F.; Escribano, V. S.; Panizza, M.; Carnasciali, M. M.; Busca, G.; Journal of Materials Chemistry 11 (2001) 1891.

[56] Gallant, D.; Pézolet, M.; Simard, S.; Journal of Physical Chemistry B110 (2006) 6871.

[57] Hadiev, V. G.; Iliev, M. N., Vergilov, I. V.; J. Phys. C: Solid State Phys. 21 (1988) L199. 